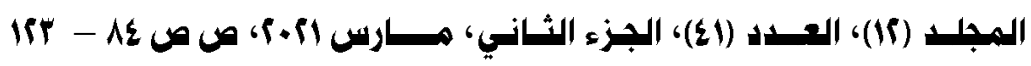

فهالالية برنامج قائم على أنماط التعلم

والتفكير في ذفض هدة صعوبات تعلم القراءة

للىى تلميذات المرحلة الابتائية بمدينة الطـائف

\title{
川 !
}

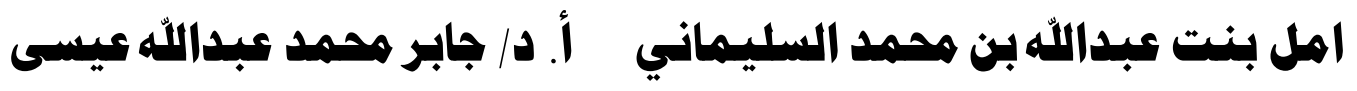
ماجستير التزبية الخاصة تخصص صعوبات التعلم أستاذبقسم التربية الخاصة -كلية التربية جسـامعـة الطــائسـف جـامعــة الطــائــف 


\section{فعالية برنامه قائم على أنماط التعلم والتفكير في خفض حدة صعوبات تعلم القراءة لدى تلميذات المرحلة الابتائية بمدينة الطائف}

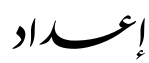

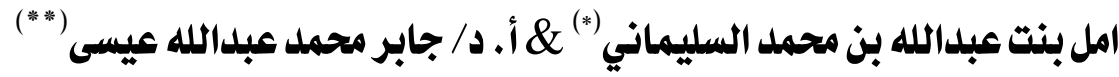

\section{ه on}

هدف البحث الحالي إلى تحديد فعالية برنامج قائم على أنماط التعلم والتفكير في خفض حدة

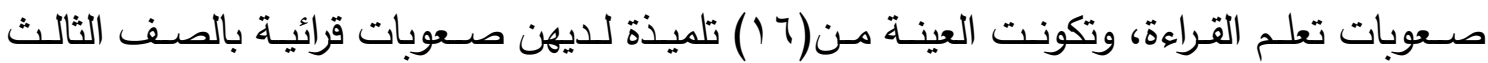
الابتدائي، وقسمت العينة إلى مجموعتين ضـابطة وتجريبية، واشتملت الأدوات: مقياس أنماط التعلم

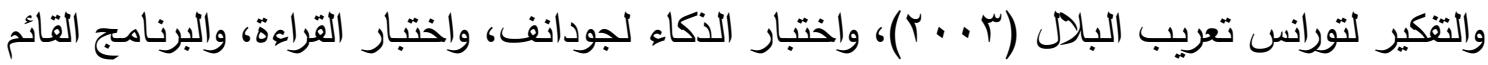

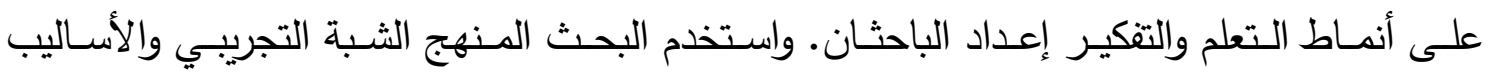

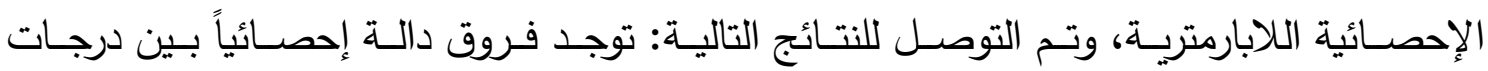
المجموعتين في اختبار القراءة البعدي لصـالح المجموعة التجريبية. توجد فروق دالة إحصـائياً بين درجات القياس القبلي والبعدي في مقياس أنماط التعلم والتفكير لدى المجموعة التجربيية فتتركز بأحد

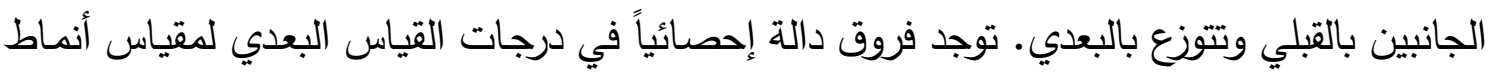

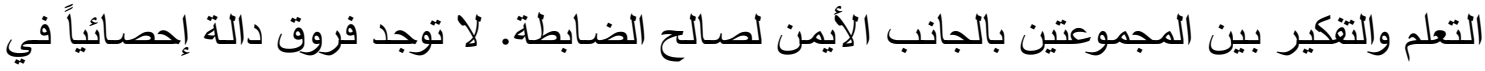
درجات القياس البعدي لمقياس أنماط التعلم والتفكير بالجانب الأيسر بين المجموعتين. توجد فروق بلين

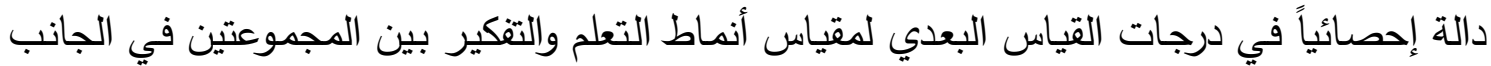
المتكامل لصالح التجريبية. توجد فروق دالة إحصائياً بين درجات القياس القبلي والبعدي في اختبار

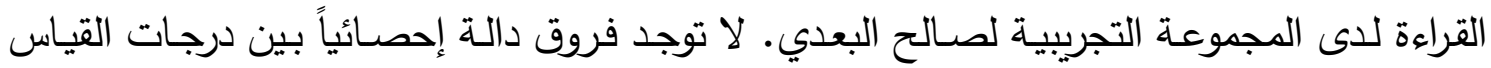

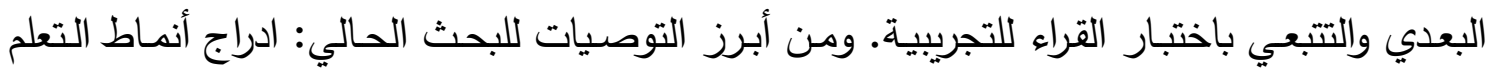
والتفكير بدليل المعلم كأحد الاستراتيجيات المستخدمة مع ذوي صعوبات التعلم عموماً وذوي صعوبة ودية القراءة بالأخص، وتدريب المعلمات عليها من خلال عقد الدورات التدريبية. وإعادة النظر في صياغة داغة منهج القراءة، والتتويع في الاستراتيجيات بحيث تتشط كافة جوانب الدماغ، وتتماشى مع كافة أنماط التعلم والتفكير • ويوصي البحث أيضاً بتقديم برامج إرشادية لأولياء الأمور بكيفية التعامل مـ أبناءهم ذوي صعوبات التعلم، وتتمية نمطهم في التعلم والتفكير، وتتشيط الأنماط الغير نشطة. الكلمات المفتاحية: فعالية برنامج، أنماط التعلم والتفكير ، صعوبات تعلم القراءة، السيطرة الدماغية. 


\title{
The effectiveness of a program based on learning and thinking styles to reduce severity of reading disability for primary school female students in Taif city
}

\author{
By
}

Amal Al-Sulaymani \& Prof. Dr. Jaber Issa $\square$

\section{Abstract $\square$}

The aim of the current research is to determine the effectiveness of a program based on learning and thinking patterns in reducing the severity of the difficulties of learning to read, and the sample consisted of (16) students with reading difficulties in the third grade, and the sample was divided into two control and experimental groups, and the tools included: a scale of learning and thinking patterns for Torrance Arabization (2003), Godanf's IQ test, reading test, and program based on learning and thinking patterns prepared by the researcher. The research used the semi-experimental method and the non-parametric statistical methods, and the following results were reached: There are statistically significant differences between the two groups' scores in the post-test reading in favor of the experimental group. There are statistically significant differences in the degrees of dimensional measurement of the scale of learning and thinking patterns between the two groups on the right side in favor of the control. There are no statistically significant differences in the degrees of post-measurement of the scale of learning patterns and thinking on the left side between the two groups. Learning and thinking between the two groups in the integrated aspect for the benefit of the experimental. There are statistically significant differences between the pre and post measurement scores in the reading test of the experimental group in favor of the postmodern.

Key words: Effectiveness Program, Learning and Thinking styles, reading disabilities, cerebral Dominance.

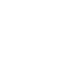


خلق الله الإنسان باحث عن المعرفة ومتعلم بطبعه، ومن أبرز ما يكوّن العلم والمعرفة لدى الإنسان القراءة، والتي تعد من أهم المهارات الدراسية التي على الطالب أن يتقنها في الصفوف الأوليـة مـن المرحلـة الابتدائيـة؛ حيث يعتمد عليها تعلم كل المـواد الأخرى، كمـا لها أهميـة في التواصل في شتى مناشط الحياة، ونجد أن الصعوبة في تعلم القراءة تسبب مشاكل كبيرة وتُصسب الحياة خصوصًا في هذا العصر الذي يندر أن نجد فيها شخصًا لا يعرف القراءة. وتعد صـعوبات تعلم القراءة من أسباب الفشل الدراسي، وهي من أبرز الصسوبات لدى التلاميذ ذوي صعوبات التعلم (أبو الديار، r ( • r، ه • (). والطلبة ذوو صعوبات التعلم يتميزون بقدرات عقلية في المتوسط أو فوق المتوسط، لكنه لا يستطيعون أن يتعلموا بالطرق التقليدية، كما أثبتت الدراسات أن الطلبة ذوي صعوبات التعلم ينجزون بشكل أفضل عندما يتعلمون بالتماشي مـع

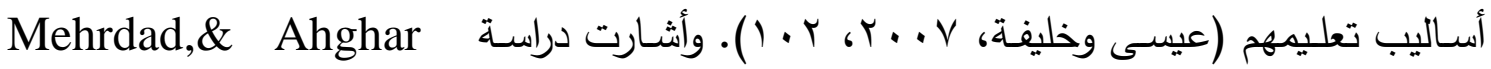

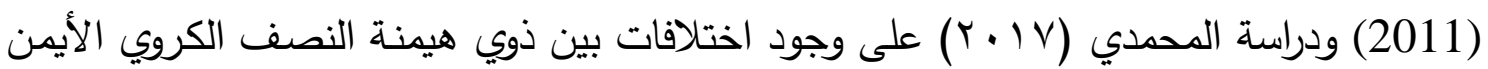
والأيسر من الدماغ في أساليب التعلم وكذلك استراتيجيات التعليم. وتثكل معرفة أنماط السيطرة الدماغية السائدة لدى المتعلمين أهمية قصوى في تحسين العملية التعليمية لكافة جوانبها وذلك من خلال التتويع في استخدام أساليب وطرق التدريس واختيار الأنشطة التعليمية المناسبة وتنظيم قاعة التدريس وإدارة عملية التعليم، بما ينعكس إيجابيًا على تحصيل المتعلمين (Sinatra, 1983). ولقد أوضـحت الأبحـاث أن كـل دمـاغ يعــل بطريقـة مختلفـة وفي مجـالات عـدّة، فكثـفت بحـوث Ornstein \& Sperry والترتيب والأرقام، أو في الأنشطة التي تسمى عادة بالأنشطة الأكاديمية. أما الجانب الأيمن فيهتم بـالنغم والتصــور واللـون وأحسـلام اليقظـة والتصــور المكـاني والنظــرة الكليـة (عبيـدات، وأبـو السميد، V . . Y، Y Y ). ويتصل نصفا الدماغ ببعضهما البعض من الداخل بواسطة حزمة كبيرة من الألياف المستعرضة البيضاء تمثل الأخدود العميق الذي يفصل بين نصفي الدماغ دون أن يكون هنالك مانع للاتصال بينهما (عقل، ؟99 1، 9 ب). ونجد أن هنالك وظائف يقوم بهما أحد النصفين 
بصورة أفضل من النصف الآخر، ولذا يستخدم مفهوم السيطرة للتعبير عن تقسيم العمل بين النصفين الكرويين ويقصد بالسيطرة الدماغية التي عبر عنها تورانس بأنها أنماط التعلم والتفكير بأن المراكز العصبية الموجودة في أحد النصفين أكثر نشاطًا وتأثيرًا في سلوك الفرد مـن المراكز العصبية الموجودة في النصف الآخر، ويذكر Solso (2004 أن هناك مرونة في نمو الدماغ وأن وظائف نصفي الدماغ ليست منفصلة بوضسوح كما كان يعتقد سـابقًا، وإنما هي مشتركة بين النصفين وبعض الأجزاء الأخرى من الدماغ.

\section{مشكاستة البحـــث:}

يعد مجال صعوبات التعلم من المجالات التي نمت بسرعة ولاقت اهتماما واسعًا، فإن أعداد

المتعلمين الذين يندرجون تحت هذه الفئة في زيادة مستمرة في الفترة الأخيرة. مما يجعل هذه الفئة

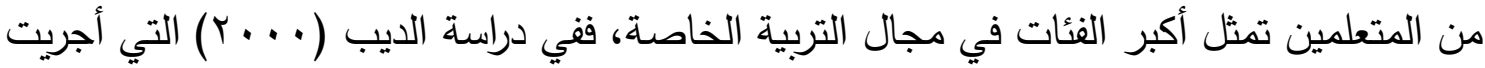
في البيئة السعودية أوضحت نتائجها أن نسبة صعوبات التعلم الأكاديمية والنمائية من (ץ- ؟ ٪\%) على مختلف المراحل وعلى المستوى الجامعي (^, r ٪). وتقدر نسبة صعوبات التعلم في المملكة

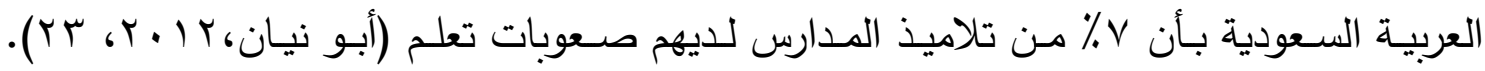
وصعوبات القراءة تمثل أكثر أنماط صعوبات التعلم الدراسية الأكاديمية شيوعًا، حيث ان ـ^\% من التلاميذ ذوي صعوبات التعلم لديهم صعوبات في القراءة، فنجده يفتقرون إلى تعلم استخدام دلالة الحروف للتعرف على الكلمات، ونجد أن لدى بی^\% من تلاميذ الصف الثاني ذوي صعوبات

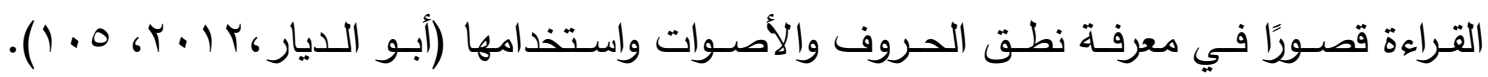
وصعوبة التعلم بهذه النسب تعد فاقدًا تعليميًا ومشكلة ينبغي التصدي لها. وترى باتمان أن عدم القدرة على التعلم "صعوبة التعلم" ترجع إلى ما يسمى بنقص السيطرة المخية (سليمان، Y ...Y، 107 (1). وترجع إلى العجز في الانتباه والتنظيم بين نصفي الدماغ والعجز في التكامل بين النظم الحسية الهختلفة (Rudel,1985). كما يشير كيم وريد إلى وجود علاقة بين اضطراب وظائف نصفي

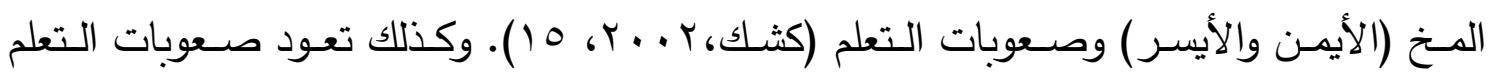

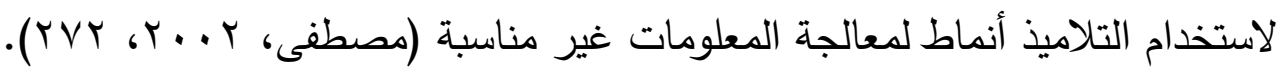


Gladstone, Best, \&Davidson,) وتحتاج مهارة القراءة إلى تكامل مهارات نصفي الدماغ

1989). وقد أشارت دراسة Aylward, Richards, Berninger, Nagy, Field, \& Grimme, (2003); Blachman, Schatschneider, Fletcher, Francis, Clonan, \& Shaywitz, (2004); Shaywitz, Shaywitz, Blachman, Pugh, Fullbright, \& Skudlarski,(2003) إلى أن التدخل المبكر والبرامج العلاجية الجيدة لذوي عسر القراءة لها آثار إيجابية في تحسن مستوى القراءة وتتشيط أجزاء الدماغ التي تكمن وراء القراءة الماهرة. وتثير الأبحاث أن التعليم التقليدي في مدارسنا يركز بطرق مباشرة وغير مباشرة على مناهج وطرق تدريس وأنشطة تعليمية تعمل على تتمية وظائف النصف الكروي الأيسر مما يؤدي إلى تتمية

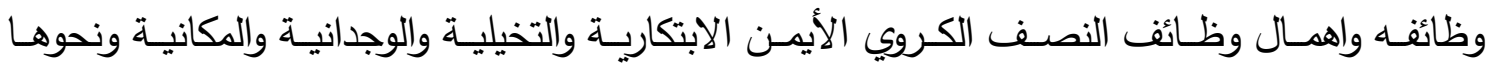

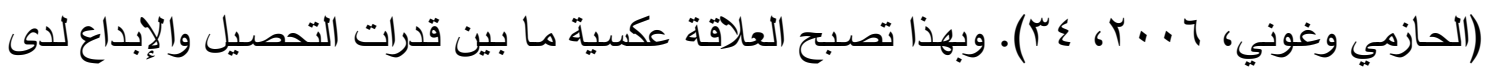
التلميذ حيث يتم التسريب أكثر من الكلازم للقدرات اللفظية والرمزية. ولهذا فإن النمطيـة في الأساليب التعليمية توقف وتعيق القدرات الابتكاريـة، أما التتوع في العملية التعليمة وتماشيها مـع عمل الدماغ الانساني تؤدي إلى إعداد أفراد يمتازون بالفكر قادرين على الإنتاج المتتوع والجديد الذي تحتاجه التنمية الشاملـة لمجتمعنـا. ولذا فهناك مسؤولية كبيرة تقع على عاتق واضـعي المنـاهج والمهتمين بأسـاليب التدريس ومعلمي ومعلمات القراءة بمختلف المراحل الدراسية، حيث ينبغي تحديد أنماط التعلم والتتكير السائدة لدى التلاميذ والتلميذات، وتخطيط وإعداد برامج ومناهج واستراتيجيات تعليمية متميزة تختلف عن تلك التي تقدم بالطريقة التقليدية وتتمي النمط الأيسر ، لتجعل التلميذ متفاعلًا مـع الموقف التعليمي، فالتعلم الفعال لابد له من الاستخدام المتكامل لوظائف النصفين في الدماغ وتطبيقها في الصف. ومن هذا المنطلق فإن البحث الحالي يسعى إلى تدارك ذلك الإثكال عند تعلم القراءة وتتمية النمط المتكامل للدماغ باستخدام برنامج مقترح لتدريس القراءة، من خلال البرنامج المقترح وتقديم استراتيجيات تدريس وتقنيات تعليم وأنشطة تعليمية تساهم في تعلم القراءة في ضوء وظائف نمط التعلم المتكامل للدماغ لاستثمار وتتمية طاقاته التي تعد مطلبًا أساسيًا في التعليم الفعال. 
تتحدد مشكلة البحث في التساؤل الرئيس التالي: ما فعالية البرنامج القائم على أنماط التعلم

والتفكير في خفض حدة صعوبات تعلم القراءة لاى تلميذات المرحلة الابتدائية بمدينة الطائف؟ ويتفرع من التساؤل الرئيس الأسئلة التالية:

ما الفروق في درجات القياس البعدي للقراءة بين المجموعة التجربيية والمجموعة الضابطة؟ ما الفروق بين درجات القياس القبلي والبعدي لمقياس أنماط التعلم والتفكير لاى التجريبة؟ ما الفروق في درجات القياس البعدي لمقياس أنماط التعلم والتفكير بين التجريبية والضابطة؟ ما الفروق بين درجات اختبار القراءة في القياس القبلي والبعدي لدى المجموعة التجربيية؟ ما الفروق بين درجات اختبار القراءة في القياس البعدي والتتبعي لدى المجموعة التجريبية؟

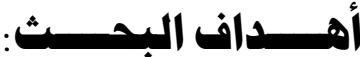

هدف البحث الحالي إلى الكثف عن: فعالية برنامج قائم على أنماط التعلم والتفكير في خفض حدة صعوبات تعلم القراءة لدى تلميذات المرحلة الابتدائية بمدينة الطائف. ويتضمن الكثف عن الأهداف الفرعية التالية: الكثف عن الفروق بين درجات القياس القبلي والبعدي لاختبار القراءة لدى المجموعـة التجريبية بعد إجراء البرنامج القائم على أنماط التعلم والتقكير • الكثف عن الفرق الذي أحدثه البرنامج لدى المجموعة التجريبية عند مقارنتها بالمجموعة الضابطة في درجات القياس البعدي في اختبار القراءة. الكثف عن الفرق الذي أحدثه البرنامج لدى المجموعة التجريبية في درجات القياس القبلي والبعدي في مقياس أنماط التعلم والتفكير • الكثف عن الفرق الذي أحدثه البرنامج لدى المجموعة التجرببية عند مقارنتها بالمجموعة الضابطة في درجات القياس البعدي في مقياس أنماط التعلم والتفكير • الكثف عن مدى ثبات أثر البرنامج بعد (ع) أسابيع من نتائج القياس البعدي في درجات اختبار القراءة لدى المجموعة التجربيية. 


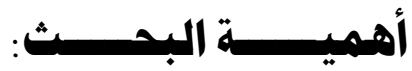

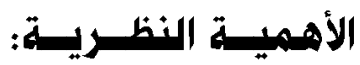

طرح طـرق وأسـاليب للتعلم المتماشـي مـع الدماغ الانسـاني والتركيز على أنمـاط التعلم والتفكير (السيطرة الدماغية) لدى المتعلم في تعلم القراءة.

يثري البحث الحالي المكتبة العربية بدراسة عن أنماط التعلم والتفكير التي نجدها قليلة في البيئة العربية وخصوصًا فيما يتعلق بصعوبات التعلم القرائية. يزود الباحثين بمعلومات عن القراءة وعن ذوي صعوبات التعلم وعن أنماط التعلم والتفكير •

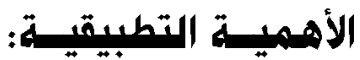

يزود المعلمين ببرنامج تطبيقي لعلاج الصعوبات القرائية قائم على أنماط التعلم والتفكير .

يزود المهتمين باختبار لتحديد صعوبات القراءة للصفوف الأولية متماشيًا مع البيئة السعودية. إيجاد استراتيجية تدريسية لعلاج صعوبات التعلم القرائية وخفض حدتها بما يعود بالفوائد على التلميذ والأسرة والمؤسسة التعليمية وعلى المجتمع بأكمله.

الحدود المكانية: مدينة الطائف.

الحدود الزمانية: الفصل الدراسي الأول لعام إــ اهـ. الحدود الموضوعية: صعوبات تعلم القراءة، وأنماط التعلم التقكير . الحدود البشرية: تلميذات الصف الثالث الابتدائي بمدينة الطائف.

همطات البمث:

أ) أنماط التعلم والتفكير (السيطرة الدماغية): اصـلاحا: يـكر مـراد وأحمد ( ( . . Y، ب I أن تورانس Torrance أشـار إلى السيطرة الدماغية على أنها أنماط التعلم والتفكير (Learning Style and Thinking) ويقصد بها استخدام الفرد للوظائف الدماغية عند مواجهة المشكلات ويتمثل في استخدام وظـائف النصفين الكرويين الأيسر أو الأيمن أو كليهما معا (المتكامل) في العمليات العقلية والسلوك. إجرائيًا: الدرجة التي تحصل عليها التلميذة ذات صعوبة القراءة في دقياس أنماط التعلم والتفكير. 


\section{ب) صعسوبـات تعلسم القــراءة:}

اصسطلاحًا: هـم التلاميذ الذين يظهـرون تباينًا واضـحًا بـين مستوى قدراتهم وتحصيلهم

الأكاديمي في القراءة، وقد يكون لديهم اضطراب في إحدى العمليات النفسية كالذاكرة والإنتباه والإدراك والتتكير، ولا تكون الصعوبات ناتجة عن عوق عقلي أو اضطراب سلوكي أو أسباب حسية

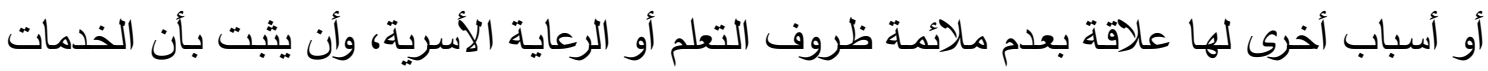
العادية غير فاعلة لتعليمهم مما يتطلب توفير خذمات خاصة (وزارة التعليم، ( • r، س؟). إجرائيًا: تم اعتماد المصنفين في برامج صعوبات القراءة في الدارس الحكومية بوزارة التعلم.

\section{ج) البرنامج التدريبي القائم على أنماط التعلم والتفكير:}

إجرائيًا: مجموعة من الإجراءات المحددة والتي تعتمد على استراتيجيات لإعمال نصفي الدماغ أثناء القراءة، بواقع اثنان وعشرون جلسة تقدم لذوات صعوبات الإترات تعلم القراءة.

\section{الإطسار النظــري والـدراسـات الســابقــة}

المحور الأول: صعوبات تعلم القراءة:

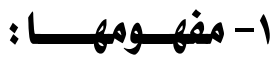

تعرف جمعية علم النفس الأمريكية (APA، 2015): صعوبات القراءة بأنها صعوبة في

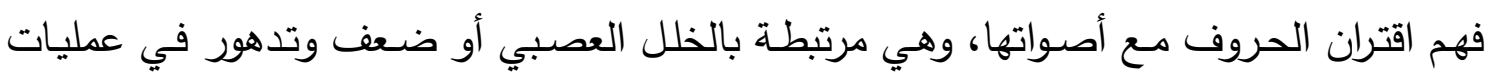
اللغة ومجالات التنكير البصري في الدماغ.

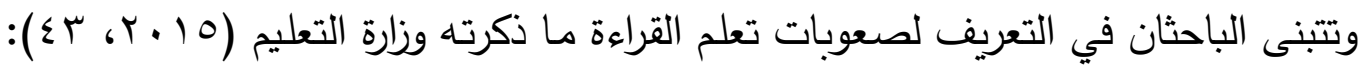
بأنهم التلاميذ الذين يظهرون تباينًا واضحًا بين مستوى قدراتهم وتحصيلهم الأكاديمي في القراءة، وقد يكون لديهم اضطراب في إحدى العمليات النفسية مثل الذاكرة والإنتباه والإدراك والتنكير ، وأن

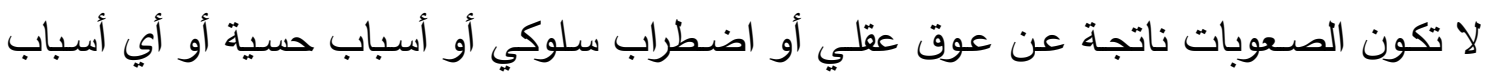

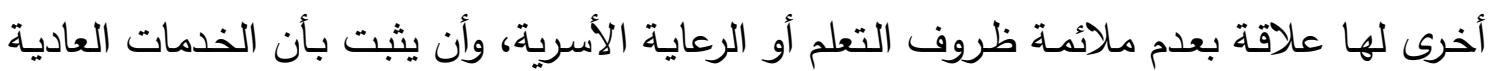

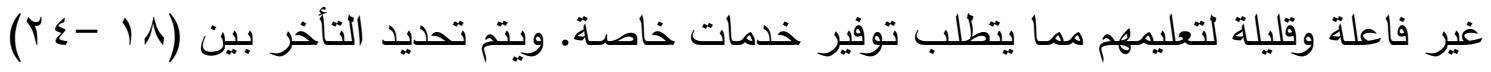
شهرًا فأكثر ، كما يجب حساب هذا التأخر بدرجات الانحراف للقيمة العادية، التي يتحصل عليها ولئ الفرد في قراءة نص مقنن مع متوسط انحراف معياري، وتتعلق هذه الدرجات المعيارية والمتوسطات الحسابية أساسًا بزمن القراءة وعدد الأخطاء والسرعة (Nuyts, 2012, 261). 
تشير الدراسات إلى وجود خلل في نظام الخلايا العصبية الكبيرة، وهذه الخلايا تصل ما بين شبكية العين والقشرة البصرية في الدماغ، وقد بِينت الدراسات التي اعتمدت على معلومات تثريحية دقيقة بالإضافة إلى تقنيات حديثة مثل التصوير بالرنين المغناطيسي أن الخلايا العصبية الكبيرة، وهي الخلايا التي تلعب دورًا حاسمًا في المساعدة على تثبيت العين على كل حرف واحدًا تلو الآخر وبالتالي تحديد ترتيب الحروف، وتبين أن المصابين بصعوبة القراءة تكون لديهم أقل

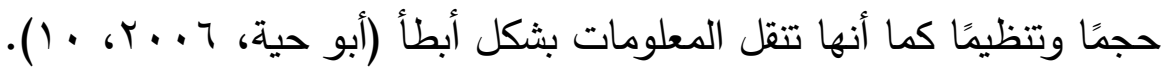

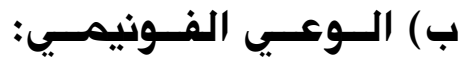

المقصود بالوعي الفونيمي أو النغمي بأنه إذا أردنا تحليل الكلمات الملفوظة إلى مركباتها فإننا نصل إلى أصغر وحدة صوتية في الكلمة والتي تسمى النغمة، ومن هنا تتطلق عملية القراءة

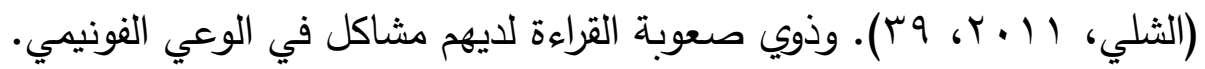
العوامل البيئية: ويُرجع بعض التربويين صعوبة القراءة لعدم توفر التدريب الملائم والفعال لمهارات القراءة، ووجود ممارسات من المعلمين تسبب وتضـاعف صعوبة القراءة لدى التلميذ ومن هذه الممارسات: ممارسة تعليم لا يتناسب مع استعدادات التلميذ، إهمال التفاعل مـع التلاميذ ذوي

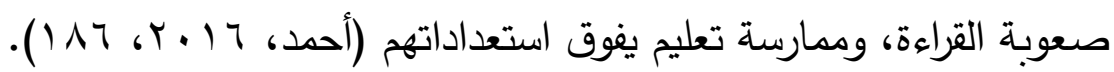
ج) عدم توفر الميل والقدرة لتعلم القراءة: والميل دافع مهم لتعلم القراءة ويرتبط الميل للقراءة بمستوى الطفل العقلي والعمر الزمني والجنس، ويعد الميل والقدرة على امتلالك المهارات

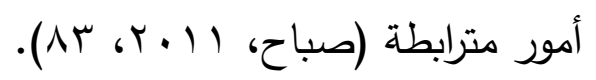

المحور الثاني: أنماط التعلم والتفكير:

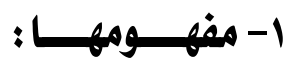
تعددت مسميات السيطرة الدماغية بتعدد واختلاف الأطر النظريـة، فقد استخدم كولمـان مصطلح عمليات الدماغ Brain Processes كمرادف للسيطرة الدماغية في حين 
استخدم زينهوسيرن Zenhausern ؛ ورفيت Rephetti وجيبارت Gebhardt تعبير التعلم

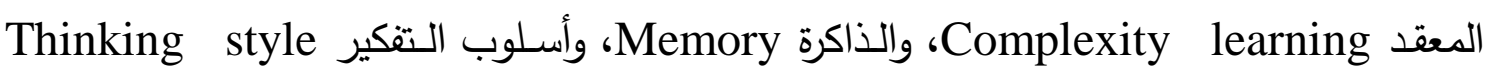
كمرادفات للسيطرة الدماغية، وأما تورانس Torrance أشار إلى السيطرة الدماغية على أنها أنماط

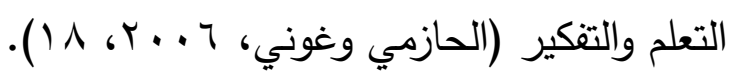
ويرجع مفهوم أنماط التعلم والتفكير أو سيطرة أحد نصفي الدماغ إلى عالم الأعصاب جون جاكسون (John Jackson) عام 1117)، الذي ركز فيها على الجانب القائد من الدماغ (The) ومنه اشتق مفهوم أنماط التعلم والتفكير، إذ عبر جاكسون عن ذلك إك

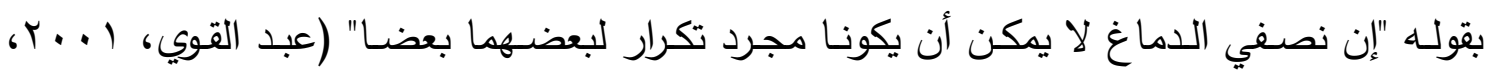

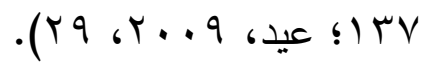
ويشير (2003) Springer \& Deutsch إلى أن أنماط التعلم والتنكير تعني تميز أحد نصفي الدماغ بالتحكم في نشاطات القرد، أو الاعتماد على أحد النصفين أكثر من النصف الآخر

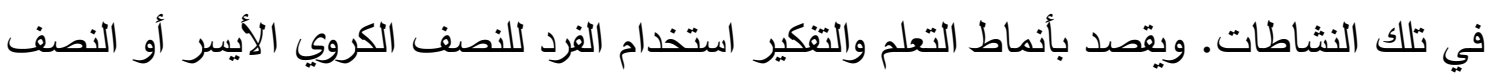
الكروي الأيمن للدماغ أو هما معـا في العمليات العقلية والمعرفية، ويمكن تلخيصها كما حددها تورانس (Torrance) فيما يلي:

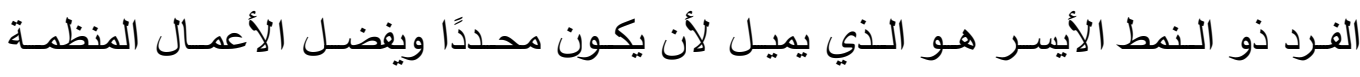
المخططة والتي يكون فيها الاكتثاف منظم متدرج عن طريق تذكر المعلومات بطريقة لفظية ليجد الحقائق المعنية، ويرتب الأفكار في صورة خطة تمكنه من التوصل إلى استتاجات لحل المشكلات وتحسين شيء ما. أما الفرد ذو النمط الأيمن فيميل لأن يكون غير محدد، ويفضل الأعمال غير المنتهية والتي يستطيع من خلالها الاستكثاف (الإبداع) عن طريق استرجاع المعلومات المكانية ليحدد الأفكار العامـة التي توضـح العلاقات في صـورة موجزة تسـاعده على إنتاج أفكار لحل المشكلات بطريقة حدسية ومن ثم يستطيع ابتكار شيء ما. وأخيرًا النمط المتكامل وهو التساوي في استخدام النصفين الكرويين للـدماغ الأيمـن والأيسـر، بحيث يعمـلان معًا تبعًا لطبيعـة المشكلة المعروضة (مراد، ع 199). 


\section{r- الاستراتيجية القائمة على أنماط التعلم والتفكير:}

تتضمن عملية التعلم الرئيسة في الاستراتيجية القائمة على أنماط التعلم والتفكير الخطوات

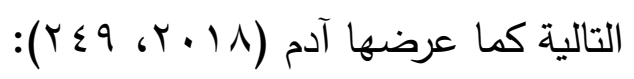

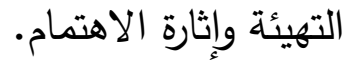

اكتساب الخبرة الجديدة وفقًا لجانبي الدماغ.

التفصيل وتعميقى الفهم (تطبيق المعرفة) لجانبي الدماغ.

تجسير وانتقال التعلم المكتسب وتعزيز جانبي الدماغ.

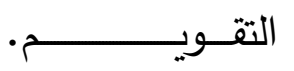

التلخيص ووضع خطة تعزيز التعلم المستقبلي.

واتبع البرنـامج القائم على أنماط التعلم والتفكير لخفض حدة صـوبات القراءة الخطوات

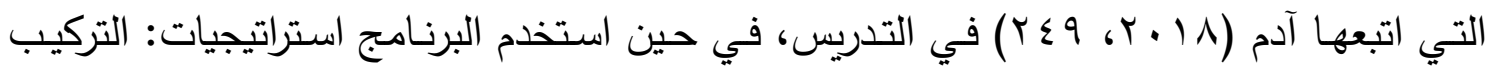
والتحليل، والخيال والمنطق، التخدين والاستنتاج، والتعليمات الحرة والدحدة، والتجريب العملي والثرح اللفظي، والألحان وإدرالك الوقت.

\section{r- أنماط التعله والتفكير وتعليم وتعلم القراءة:}

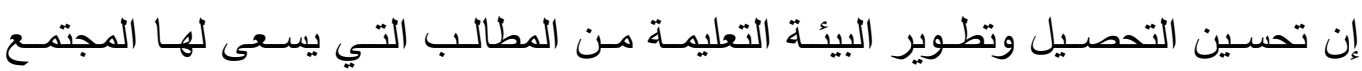
والباحثين، وقد أثار الباحثون إلى أن التدريس باستخدام أنماط التعلم والتفكير في العملية التعليمية عموماً وفي تعلم القراءة خصوصاً، تأثير إيجابي في التحصيل وتتشيط للقدرات الدماغية. ويمكن أن يسهم تعليم وتعلم القراءة بالتركيز على تتمية وظائف النصفين الكرويين للدماغ، وخاصـة تتميـة نمط التعلم والتتكير الأيمـن للدماغ المهمل، حيث يتم استخدام عمليات البحث والتقصي، واستخدام الطريقة الكلية والأنثطة في تدريس القراءة، والاهتمام بتحفيز قدرة الطالبة على التخيل وإنتاج المقارنـات، فينبغي عند اكتسـاب التلميذات للمعـارف والمعلومـات تتشيط وظـائف

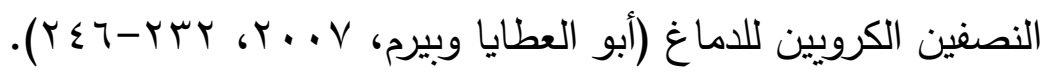




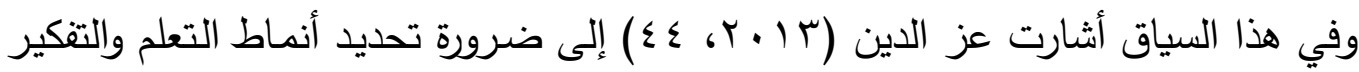
للتلميذات، وتصنيفهن إلى متعلمة بالنصف الكروي الأيمـ، ومتعلمة بالنصف الكروي الأيسر، ومتعلمة بالنصفيين معًا، فمن خلال ذلك يمكن: التكامل بين عمل النصفيين الكرويين للدماغ من خلال أنثطة وبرامج تعلم القراءة، حيث ترى نظريـة التعلم المستتد إلى الدماغ أن السيطرة الدماغيـة لا تعكس استخدام الجانب الأيمن والأيسر فقط بقدر ما تدل على أننا طورنا بعض قدراتتا ولم نطور قدرات أخرى. اختيار الاستراتيجيات والأساليب المناسبة لتعليم وتعلم القراءة، وهذا يعد أداه لقياس الفروق الفرديـة للتلميذات، وبالتالي منح التلميذات الفرصـة للتوصل إلى الأدوات التي يمكن أن تساعدهن في تعلم القراءة في المواقف المختلفة. وفي ضوء مما سبق ترى الباحثان الأهمية الكبيرة للتعرف على أنماط التعلم والتنكير للى تلميذات المرحلة الابتدائية وخصوصًا تلميذات الصف الثالث الابتدائي من ذوات صعوبات تعلم القراءة وتطوير قدراتهن في القراءة بـاختلاف نمط السيطرة الدماغية (الأيمن، الأيسر ) لتحسين تحصيل التلميذات في القراءة.

\section{الــدراســات الســابقة}

هناك عدد من الدراسات السابقة التي ربطت ما بين صعوبات التعلم والسيطرة الدماغية ومنها: دراسة (1989) .Gladstone, et al التي أجريت بهدف المقارنة بين العاديين وذوي عسر القراءة في إعمال نصفي الدماغ وطبقت الدراسة على عينة مكونة من (דب) تلميذًا تتراوح أعمارهم بين (9-ـ ( ) عام وقسمت لمجموعتين (1) (1) تلميذ يعانون من عسر القراءة و(1 ( ) من العاديين وتم اختبار أدائهم وتوصلت النتائج أن للى ذوي عسر القراءة مشاكل في التكامل بين نصفي

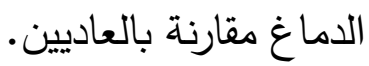
وكذلك دراسة (2003) Aylward, et al التي هدفت إلى تقييم آثار تعليم القراءة على التتشيط الدماغي عند الأطفال الذين يعانون من عسر القراءة، وتكونت عينة البحث من (· ( ) أطفال مصابين بعسر القراءة و(1 (1) قارئًا عاديًا تم فحص fMRI عليهم، ثم تم التدخل للذين 
يعانون من عسر القراءة ببرامج للقراءة شاملة بمعدل (Y^) ساعة. وتوصلت النتائج: إلى فروق بين الاختبار القبلي والبعدي لصالح الاختبار البعدي. فقبل العلاج، أظهروا تتشيط أقل في جانبي المـخ الأيمن والأيسر ، أما بعد العلاج أظهروا تحسن في نتائج القراءة وزيادة تتشيط الدماغ. وهدفت دراسة Nussbaum (2010) قياس مدى فاعلية برنامج تدريب المخخ يتضمن (ألعابًا دماغية) في تحسين الأداء المعرفي والسلوكي والأكاديمي للى الأطفال ومعرفة التأثيرات العصبية التي يحدثها البرنـامج. وتكونت عينـة الدراسـة من (ع بام) تليمذًا وتلميذة موزعين إلى مجموعتين ضابطة وتجريبية من المعرضين لخطر الإصابة بصعوبات تعلم القراءة والرياضيات. وأسفرت النتائج عن فعالية البرنامج التدريبي في تحسين الأداء السلوكي والمعرفي لدى العينة التجريبية.

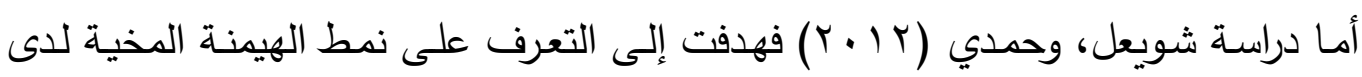
تلاميذ المرحلة الابتدائية من ذوي عسر القراءة. وتكونت عينة الدراسة من (•r) تلميذا وتلميذة تم اختيارهم بأسلوب المعاينة الاحتمالية القصدية من تلاميذ السنة الثانية والثالثة ابتدائي. وأظهرت نتائج الدراسـة عدم صـحة الفرض الأول الذي نص على " هيمنـة النمط الأيمـن للدى التلاميذ المعسرين قرائيا"، في حين أثبتت صحة الفرض الثاني الذي نص على "عدم وجود هيمنة مخية تامة لاى التلاميذ المعسرين قرائيا في عينة البحث"، ونفت النتائج المتوصل إليها من خلال نتائج البحث مـا نصت عليه الفرضية الثالثة في البحث التي نصت بدورها على" وجود اختلاف بين الجنسين في أنماط الهيمنة المخية لاى تلاميذ العينة المدروسة". وتبين من خلال هذه الدراسة أن

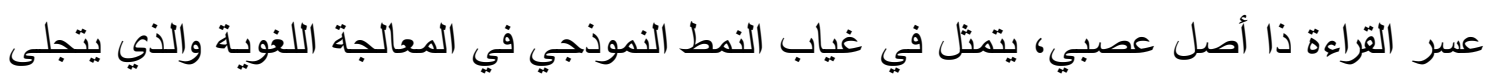
في اللاتناظر الوظيفي بين نصفي المخ بالنسبة للغة.

في حين أن دراسـة السمان (10 ب ب) هدفت إلى عـلاج صـعوبات القراءة لدى تلاميذ المرحلة الابتدائية من خلال برنامج قائم على التعلم المستتد على الدماغ. وتم اختيار عينة مكونة من (· · تلميذًا بالصف الرابع الابتدائي بمحافظة القاهرة بمصر • وتوصلت الدراسة إلى فعالية نظريـة التعلم المستتد على الـدماغ لعـلاج صـعوبات القـراءة في النطـق والتعـرف والفهم ومـن الاستراتيجيات التي اعتمد عليها البرنامج تتشيط جانبي الدماغ. 
أما دراسة, Richards, Grabowski, Boord, Yagle, Askren, Mestre, Robinson, Welker, Gulliford, Nagy, \& Berninger, (2015) الدماغ بين العاديين وذوي صعوبات الكتابة والقراءة. وتكونت العينة من ثلاث مجموعات مجموعة من

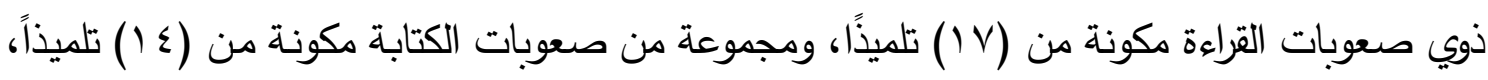

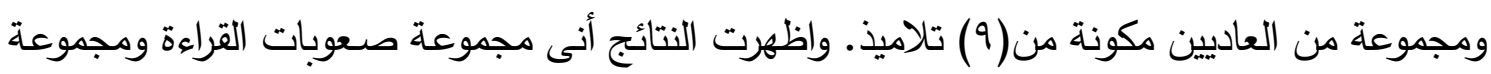

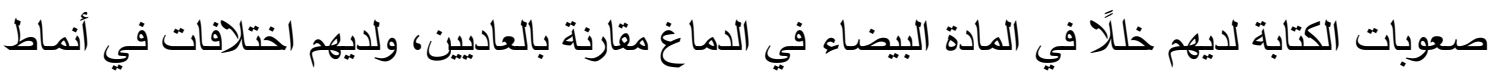
التوصيل الوظيفي للمهـة وكذلك اختلافات في مناطق التوصيل في نصفي الدماغ الأيمن والأيسر واختلافات في أنماط الارتباطات بالنسبة لمجموعة العاديين. وأثارت دراسة محمود وشوكت وحموده (Y V V V) إلى اختبار مدى فعالية برنامج للنصف الأيمن من المخ لعلاج صعوبات التعلم غير اللفظية لأطفال المدرسة الابتدائية. وتكونت عينة البحث من ستة أطفال ذوى صعوبات التعلم غير اللفظية بالددرسة الابتدائية. وكثفت النتائج عن حدوث تحسن في المجـال اللفظي للذكاء لـدى المجموعـة التجريبيـة مـن أطفـال المدرسـة الابتدائيـة ذوى صعوبات التعلم غير اللفظية بعد البرنامج، وتحسن المجال الأدائي أو العملي للذكاء للى المجموعة التجريبية، وتحسن العمليات المعرفية الأربعة في منظومة التقييم المعرفي (عملية التخطيط، عملية الانتباه، عملية التأني، عملية التتابع)، وتحسن الأداء على اختبار الثكل المعقد لرأى - اوستريث -، وأيضا تحسن الأداء على اختبار بندر جشتطالت البصرى الحركي لاى المجموعة التجريبية.

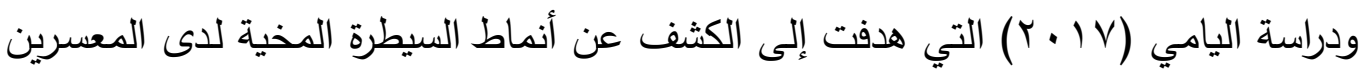
قرائيًا وعلاقتها بالذكاء اللغوي، وتمت الدراسة على عينة مكونة من (• ع ب) تلميذة، منهن (1 • ( ) تلميذات عاديات، (r T ( ) معسرات قرائيًا من المدارس الحكومية بمدارس نجران، وتوصلت الدراسة إلى أن النمط السائد لدى المعسرات قرئيًا هو النمط الأيمن، ووجود علاقة سالبة غير دالة بين نمط لئ السيطرة الأيمن ومستوى الذكاء اللغوي.

وأما دراسة (2018) Dimitriadis, Simos, Fletcher, \& Papanicolaou فهدفت إلى الكثف عن طريقة عمل الدماغ لاى الأفراد الذين يعانون من صعوبات قرائية. وتكونت العينة من (Y0) من الذين يعانون من صعوبات قرائية شديدة، و(YV) من الذين لا تتوافق قراءتهم مـع 
عمرهم الزمني، وتتراوح أعمار أفراد العينة من V-ـ ا سنة. وأظهرت النتائج أن الذين يعانون من عسر القراءة الثديد لديهم مجموعة من التشوهات الوظيفية في الدماغ حيث كانت كفاءة الوصلات العصبية لديهم ضعيفة، أما الذين لا تتوافق قراءتهم مع عمرهم الزمني فكانت لديهم نسبة أعلى من

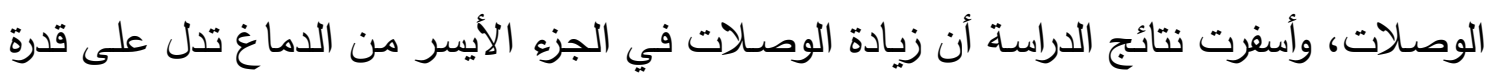
قرائية وقدرة على اكتساب المهارات القرائية. ونجد أن دراسة (2018) Peters, Bulthé, Daniels, Beck, \& Smiedt هدفت إلى مقارنة نشاط الدماغ للأطفال المصابين بعسر القراءة، والأطفال الذين يعانون من عسر الحساب، والأطفال الذين يعانون من عسر القراءة والحساب معًا. وتكونت العينة من باط طفلًا تتراوح أعمارهم بين 9 و r I ا عام، تم تقسيمهم لثلاث مجموعات مجموعة لديها عسر قراءة ومجموعة لديها عسر حساب ومجموعة لديها كلا الاضطرابيين. وأثـارت نتائج التحليلات إلى تثابه عصبي كبير بين الأطفال الذين يعانون من اضطرابات التعلم، وأظهرت المقارنة المباشرة بين مجموعات الأطفال الذين يعانون من اضطرابات في التعلم مستويات مماثلة من التتشيط العصبي في جميع أنحاء الدماغ.

في ضوء الدراسات السابقة ونتائجها والإطار النظري تم وضع الفروض التالية: 1-توجد فروق دالة إحصائياً بين درجات المجموعة الضابطة والمجموعة التجريبية في اختبار والطيار القراءة البعدي لصالح المجموعة التجريبية. r- لا توجد فروق دالة إحصائياً بين درجات القياس القبلي والبعدي في مقياس أنماط التعلم والتنكير لاى المجموعة التجريبية. r- لا توجد فروق دالة إحصائياً في درجات القياس البعدي في مقياس أنماط التعلم والتفكير بين المجموعة التجريبية والضابطة. ع - توجد فروق دالة إحصائياً بين درجات القياس القبلي والقياس البعدي في اختبار القراءة لاى المجموعة التجريبية لصالح القياس البعدي.

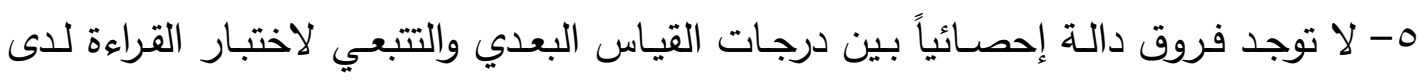
المجموعة التجريبية. 
اعتمد البحث على المنهج شبه التجريبي، وذلك لبحث أثر المتغير المستقل وهو: البرنامج القائم على أنماط التعلم والتفكير، على المتغير التابع وهو صعوبات القراءة لدى عينة من تلميذات الصف الثالث الابتدائي ذوات صعوبات القراءة، وتم تقسيمهن لمجموعتين ضابطة وتجريبية، وضبط المتغيرات التي من المكن أن تؤثر على تكافؤ المجموعتين الضابطة والتجريبية وهي: الذكاء والعمر والجنس، ثم تم تطبيق أدوات القياس القبلي على المجموعتين المتضمنة (اختبار القراءة من إعداد

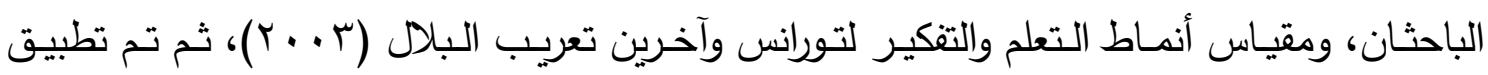
البرنامج القائم على أنماط التعلم والتنكير على المجموعة التجريبية، ثم طبقت أدوات القياس البعدي لتعبي على المجموعتين لمعرفة أثر البرنامج على المجموعة التجريبية والفروق بين المجموعتين.
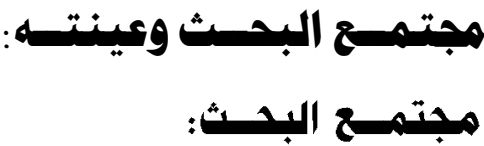

يتألف مجتمع البحث من التلميذات ذوات صعوبات القراءة بالصف الثالث الابتدائي بمدينة الطائف بالمدارس الحكومية، وهي ثمانية وعشرون مدرسة حكومية داخل مدينة الطائف تشتمل على برامج لصعوبات التعلم، وعدد تلميذات الصف الثالث الابتدائي ذوات صعوبات القراءة أربعين تلميذة.

عينـة البحث الاستطلاعية: تم اختيار (بr) تلميذة من العاديات ومن ذوات صعوبات التعلم بالمدارس الحكومية بمدينة الطائف، والمدارس هي: (الابتدائية الثالثة، والخامسة، والحادية عشر، والتاسعة عشر، والعشرون، والثامنة والخمسون، والأولى بالحوية).

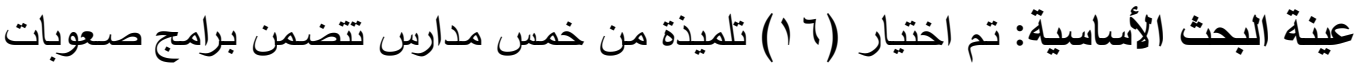
التعلم بالمدارس الحكومية بمدينة الطائف، وهي كالتالي: الابتدائية الثالثة بها تلمذنين، والابتدائية العشرون بها ثلاث تلميذات، والابتدائية الخامسة عشر بها ثلاث تلميذات (المجموعة التجريبية ثمان تلميذات)، والابتدائيـة التاسعة عشر بهـا ثـلاث تلميذات، والابتدائية الرابعـة والعشـرون بها خمسـة تلميذات (المجموعة الضابطة ثمان تلميذات). وجميعهن مصنفات كتلميذات ذوات صعوبات قراءة وتحددت العينة من خلال الخطوات التالية: طلب الإحالة من خلال ملاحظة المعلمة أو الأسرة أو من سجلات المدرسة. 
المقابلة مع المعلمة للكثف عن المستوى الأولي للتلميذة والمشاكل التي تواجهها والتأكد من استخدام التعليم المناسب لقدرات ومستوى التلميذة.

مراجعة الفحص الطبي للتلميذة. مراجعة استبانة الحالة الاجتماعية. مراجعة الاختبار النمائي. تطبيق اختبار رسم الرجل لقياس الذكاء. تطبيق اختبار القراءة من إعداد الباحثان. تطبيق مقياس أنماط التعلم والتفكير لتورانس تعريب البلال( ( . ץ). تقسيم الستة عشرة تلميذة من ذوات صعوبات القراءة لمجموعتين مجموعة ضـابطة مكونـة من ثمان تلميذات، ومجموعة تجريبية مكونة من ثمان تلميذات. التحقق من التكافؤ بين المجموعتين التجربيية والضابطة. وللتحقق من تكافؤ المجموعتين التجريبية والضابطة في متغير (الذكاء، ودرجات القراءة، وأنماط التعلم والتفكير، والعمر الزمني) تم استخدام اختبار مان ويتتي كما هو موضح في الجدول التالي: جلول (1) التكافؤ بييز المجموعتين التجريبية والضابطة في بعض المتفيرات

\begin{tabular}{|c|c|c|c|c|c|c|}
\hline مستوى الدلالة & | قيمة مان ويتني U & |قيمة Z & |مجموع الرتب | مجب | & متوسط الرتب & المجمهـــوعـــات & المتفــــيرات \\
\hline \multirow{2}{*}{ VYI. } & \multirow{2}{*}{$r \wedge, \cdots$} & \multirow{2}{*}{ 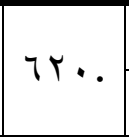 } & $V Y, \cdot$ & $9, \cdots$ & التجريبية (ن =N ) & \multirow{2}{*}{ 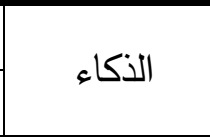 } \\
\hline & & & $7 \varepsilon$, & $\wedge, \cdots$ & الضابطة (ن =N ) & \\
\hline \multirow{2}{*}{ VYI. } & \multirow{2}{*}{$r \wedge, \cdots$} & \multirow{2}{*}{$\leq r)}$. & $7 \varepsilon$, & $\wedge, \cdots$ & التجريبية (ن = N ) & \multirow{2}{*}{ درجات القراءة } \\
\hline & & & $V Y_{,} \cdot$ & $9, \cdots$ & الضابطة (ن = م ) & \\
\hline \multirow{2}{*}{ rYA. } & \multirow{2}{*}{$r, \ldots$} & \multirow{2}{*}{$1, \ldots 0$} & $V V, 0$ & 9,79 & التجريبية (ن = A ) & \multirow{2}{*}{ النمط الأيمن } \\
\hline & & & $0 \wedge, 0$ & $\vee, r_{1}$ & |الضابطة (ن =N ) & \\
\hline \multirow{2}{*}{ r人r. } & \multirow{2}{*}{$r r, \ldots$} & \multirow{2}{*}{ 90\%. } & 09, & $\vee, r \wedge$ & التجريبية (ن =N ) & \multirow{2}{*}{ النمط الأيسر } \\
\hline & & & $V V, \cdot$ & $9,7 r$ & الضابطة (ن =N ) & \\
\hline \multirow{2}{*}{ OV $\varepsilon}$. & \multirow{2}{*}{$r q, \cdots$} & \multirow{2}{*}{779.} & $7 r$, & $V, V O$ & التجريبية (ن = N ) & \multirow{2}{*}{ المتكامل } \\
\hline & & & $V Y, \cdot$ & $9, r_{0}$ & الضابطة (ن =N ) & \\
\hline \multirow{2}{*}{$1, \cdots$} & \multirow{2}{*}{$r, \ldots$} & \multirow{2}{*}{$\cdots$} & $71, \cdot$ & 1,0 & التجربية (ن = N ) & \multirow{2}{*}{ العمر الزمني } \\
\hline & & & $71, \cdot$ & $\Lambda, 0$ & الضابطة (ن =N ) & \\
\hline
\end{tabular}


ويتضح من الجدول السابق أن الفروق بين المجموعتين التجريبية والضـابطة غير دالة من حيث درجة الذكاء، ومستوى القراءة، ودرجات مقياس أنماط التعلم والتنكير، والعمر الزمني مما يدل على تكافؤهما، كذلك تتكافىء المجموتين التجريبية والضابطة في الجنس حيث أن جميعهن إناث.

أعدت هذا الاختبار الباحثان الأمريكية جودانف Goodenough فى عام • ب 19 كاختبار

للذكاء، وهذا الاختبار لا يتطلب من الطفل أكثر من أن يرسم صورة لرجل، وطبقته على عينـة مكونة من . .ـ طفل أمريكى من تلاميذ رياض الأطفال بولاية نيوجرسى ومن خلال النتائج تم التوصل إلى أنه يمكن اتخاذ •ـ مفردة كمقياس للقدرة العقلية عند الأطفال ويُعطى كل عنصر درجة واحدة ثم تجمع الدرجات ويتم حساب نسبة الذكاء المقابلة للدرجات، ويؤكد هذا الاختبار على دقة الطفل فى الملاحظة ونمو تفكيره المجرد وليس المهارة الفنية فى الرسم. ولكن بعد ذلك أضافت

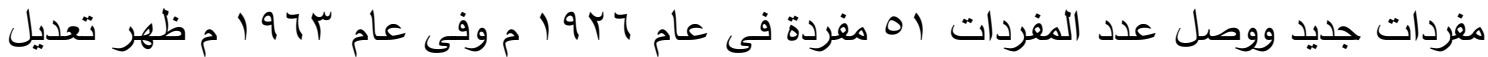
جديد لهذا الاختبار باسم رسم الرجل لجودانف وهاريس ووصل فيه عدد المفردات VT مفردة، وتم ترجمة هذا الاختبار للعديد من اللغات والبلاد حيث تم تتنينة فى البيئة المصرية (مصطفى فهمى، د. ت ) والأردنية وقام فريق من الباحثين بتقنين المقياس على البيئة السعودية على المنطقة الغربية (أبوحطب وآخرون، 9 (1) ). وتم حساب صدق وثبات الاختبار بواسطة العديد من الباحثين فى

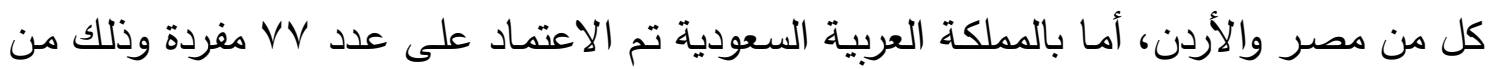
خلال تطبيقه على عدد تمتد أعمارهم من ب- 10 عام، وتم التأكد من صدق الاختبار فى البيئة السعودية من خلال صدق المقارنة الطرفية، وتم استخدام صدق التكوين الفرضى حيث تحدث زيادة فى المتوسطات بالزيادة فى العمر وأيضاً تم حساب الصدق المرتبط بالمحكات حيث تم حساب معاملات الارتباط بدرجات اختبار مصفوفات رافن (أبوحطب وآخرون، 9 (1)م). 
وفي دراسة على أطفال منطقة الطائف تم تطبيق اختبار رسم الرجل واختبار ستانفورد بينيهـ على 10 طفلًا وطفلـة وبحسـاب معامل الارتباط بين نسب الذكاء مـ الاختبارين كانت צrV, • مما يؤكد صدق اختبار رسم الرجل. أما عن الثبات فقد تم إعادة تطبيق اختبار رسم الرجل على 10 طفلًا وطفلة بفاصل زمنى ثلاثة أسابيع وتم حساب معامل الارتباط بين درجات التطبيقين

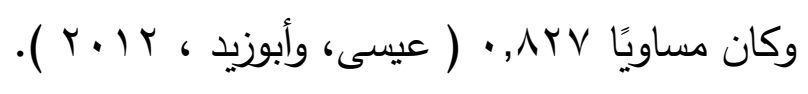

\section{r- اختبار القراءة من إعداد الباحثان:}

صُمـم الاختبـار بهدف قيـاس قدرة التلميذة في التعـرف على الكلمـة وقراءتهـا بصـورة صـحيحية، وتحديـد درجـة صـوبة التعرف على الكلمـة لـى التلميذات ذوات صـعوبات القـراءة بالصف الثالث الابتدائي.

\section{خطـوات إعــاد الاختبـار:}

الإطلاع على الأدب النظري والدراسات السابقة على سبيل المثال دراسة (الفرا، ج ( ب)، و

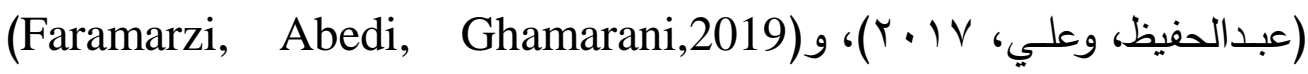

. (Harold, 2019)

الاطلاع على بعض اختبارات القراءة ومنها (Faramarzi,et.al.,2019) و (عبدالحفيظ،

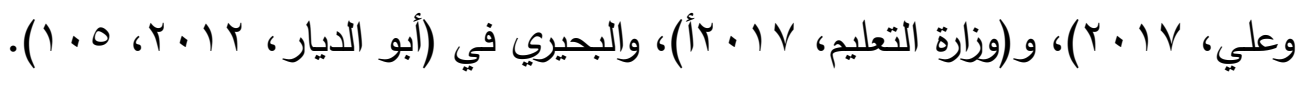

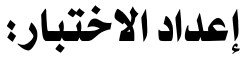

$$
\text { تكون الاختبار من: }
$$

مقدمة تتضمن البيانات العامة للتلميذة.

ه تعليمات للاختبار وكلمات تجريبية توضح طريقة الاختبار .

الاختبار المكون من واحد وعشرين كلمـة متدرجة في الصعوبة، ومشتملة على مهارات متعددة يجب اتقانها للتعرف على الكلمة، ومنوعـة بين أسماء وأفعال، وتم بناءها وفق المهارات المطلوبـة للتعرف على الكلمـة، بنـاءًا على الزيـارات الميدانيـة لترتيبهـا وانتقـاء 
الكلمـات المناسبة، وتم عرض الاختبار في صـورته الأوليـة على خمس معلمـات مـن معلمات الصف الثالث الابتدائي للتأكد من مألوفية الكلمات لمستوى الصف الثالث وبناء على ذلك تم تعديل بعض الكلمات واستبدال البعض الاخر . هفتاح التصـيح حيث يتم وضـع علامـة صـح عند الكلمـة التي يتم قراءتها بصورة صحيحة وتحسب لها درجة، وعلامة خطأ عند الكلمة التي تقرأ بطريقة خاطئة وتحسب صفر ، ثم يتت حساب عدد الكلمات الصحيحة التي تم قرائتها في دقيقة ووضع الدرجة الكلية من واحد وعشرين.

\section{الخصائص السيكومتزية للاختبار:}

تم تطبيق الاختبار على عينة استطلاعية من غير عينة البحث، مكونة من ثلاثة وثلاثين تلميذة من تلميذات الصف الثالث الابتدائي من العاديات ومن ذوات صعوبات التعلم بالمدارس الحكومية بمدينة الطائف، والددارس هي: (الابتدائية الثالثة، والخامسة، والحادية عشر ، والتاسعة

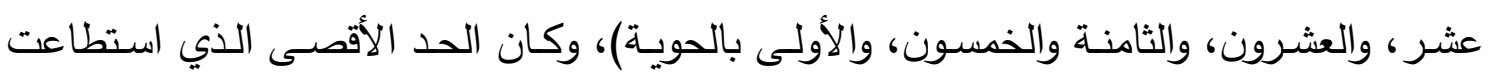
التلميذات قراءته (Y) كلمة فقط في الدقيقة الواحدة، لذا تم حساب الصدق والثبات على هذا العدد من الكلمات وتم التحقق من الصدق والثبات وحسابهما على النحو التالي:

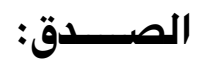

\section{صـدة الاتسـاؤ الـــافلـيـ:}

تم حساب صدق الاختبار لواحد وعشرين كلمة صحيحة تُقرأ في الدقيقة الواحدة وارتباطها بالدرجة الكلية بطريقة بيرسون وتتراوح نتائج الصدق ما بين367. و804. وجميع المعاملات دالة إحصائيًا، مما يشير إلى صدق اختبار القراءة.

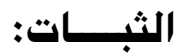

تم تقسيم كلمات الاختبار الواحدة والعشرون إلى كلمات فردية وأخرى زوجية، ثم حسابها كما في الجدول التالي:

جدول (r) ثبــــات اختبــــار القـــــراءة

\begin{tabular}{|c|c|c|c|}
\hline معامل ألفا كرونباخ & معامل جثمان & معامل سبيرمان - براوذ & معامل الارتباط \\
\hline$\cdot, \wedge r$. & $\cdot, 9 \cdot V$ & $\cdot, 9 \cdot V$ & $\cdot, \wedge r$. \\
\hline
\end{tabular}


يتضح من الجدول السابق ارتفاع معامل ثبات الاختبار بدرجة مقبولة مما يؤكد صـلاحية الاختبار للاستخدام في البحث الحالي.

\section{مقياس أنماط التعله والتفكير لتورانس وآخرين تعريب البلال (ץ+.r) ؛}

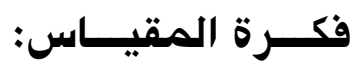

أعد هذا المقياس تورانس وآخرون عام (1977)وتقوم فكرة مقياس أنماط التعلم والتفكير

على تحديد الفص الدماغي (أيمن - أيسر - أو متكامل) الأكثر استعمالًا عند الفرد عند مواجهة المشكلات والتعلم، حيث بتحديد نمط السيطرة يتم تحديد طريقة التعلم المفضلة والأسلوب المستخدم من قبل الفرد عند التعلم والتفكير ومواجهة المشكلات، وقد يتعارض أسلوب المعلم مع نمط التلميذ؛ فيؤدي لسوء فهم وظهور صسوبات تعلم، أو قد يقتصر التدريس على أسلوب ينمى أحد الفصين ويهمل الآخر مما يضيع الكثير من القدرات الدماغية.

وصــف المقيــاس:

يشمل المقياس في صورته (أ) المعدة للصغار ثمانية وثلاثون مجموعة من العبارات، حيث أن كل مجموعة تحتوي على ثلاثة اختيارات مختلفة متعلقة بوظائف النصفين كروين للدماغ حيث تتعلق إحدى العبارات بالنصف الأيمن للدماغ والأخرى بالنصف الأيسر للدماغ والثالثة بالمتكامل.

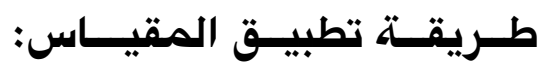

يطبق المقياس بصورة جماعية مع التأكد من فهم التلميذات لعباراته، ويمكن توضيح وشرح بعض العبارات للتلميذات، ثم يطلب من التلميذة بعد قراءة العبارات اختيار أحد الاختيارات التي تصفها بدرجة أكبر من غيرها وذلك بوضـع علامـة (ل ل) أمام العبارة، وغير مسموح باختيار أكثر من عبارة في كل مجموعة من العبارات، ويستغرق تطبيق المقياس حوالي هب دقيقة.

\section{الخصائص السيكومترية للمقياس :}

تم تحكيم البرنامج من قبل تسعة محكمين من أساتذة الجامعة وتم تعديل م رأوه مناسباً، كما تم تطبيق المقياس على عينة البحث الاستطلاعية ( ن=سب تلميذة)، والتوصل إلى الصدق والثبات وتم حسابهما على النحو التالي: 
صـدق الاتسـاق الـداخلي: وتراوحـت درجـات الصـدق مـا بـين 35. و76. حيـث جميـع

المعاملات دالة إحصائيًا، مما يشير إلى صدق مقياس أنماط التعلم والتفكير •

تم حساب ثبات مقياس أنماط التعلم والتفكير للبحث على العينة الاستطلاعية المكونة من سب تلميذة بطرق عدة وهي طريقة التجزئة النصفية والفا كرونباخ والجدول التالي يوضتح النتائج: جلول (r) ثبات مقياس أنماط التعلم والتفكير

\begin{tabular}{|c|c|c|c|c|}
\hline معامل ألفا كرونباخ & معامل جثمان & معامل سبيرماز-براوز & معامل الارتباط بين النصفين & 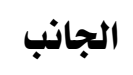 \\
\hline$\cdot, T \wedge Y$ & $T V V$. & Vrv. & O^乏. & الأيمن \\
\hline$\cdot, T \leqslant Y$ & $V \cdot r$. & VII. & oor. & الأيسر \\
\hline$\cdot, \mathrm{V} \odot \Lambda$ & $\wedge)$. & Nrq. & $V \cdot \Lambda$. & المتكامل \\
\hline
\end{tabular}

ومن الجدول السابق يتضح أن مقياس أنماط التعلم والتفكير له قيم ثبات جيدة.

البرنامج القائم على أنماط التعلم والتفكير لخفض حلدة صعوبات تعلم القراعة للدى تلميـذات الصف الثالث الابتدائي من إعداد الباحثان.

هـدف البـرنامــج:

هدف البرنامج إلى خفض حدة صعوبة القراءة (التعرف على الكلمة) لدى تلميذات الصف الثالث الابتدائي. وينبثق من هذا الهدف العام مجموعة الأهداف الفرعية التالية التي يسعى البرنامج لتحقيقها لدى أفراد العينة التجريبية وهي: تركيب الحروف لتكون مقاطع وتركيب المقاطع لتكون كلمات. تحليل الكلمات لمقاطع والمقاطع إلى أصوات. قراءة كلمات مع الحركة الطويلة والقصيرة والساكنة.

قراءة كلمات بها ظواهر لغوية (التاء المربوطة والمفتوحة والهاء -اللام الثمسية والقمريـة التضعيف-التنوين). 


\section{الأسـاس النظـري للبـرنـامـج:}

بعد الاطلاع على الإطار النظري ذا الصلة بذوي صعوبات التعلم وأنماط التعلم والتفكير

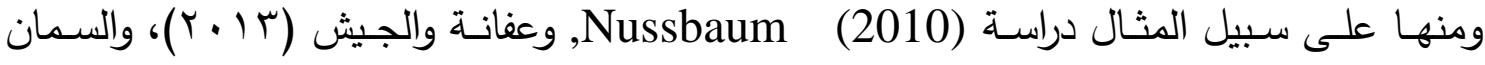

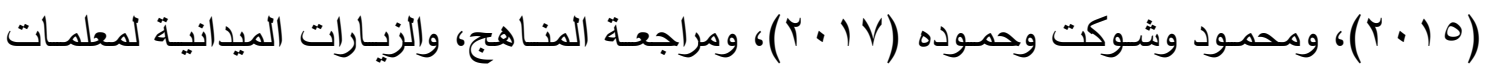
صعوبات التعلم، استندت الباحثان في إعداد البرنامج على أنماط التعلم والتفكير والتتويع بين نمط التعلم المعتمد على النصف كروي الأيسر والأيمن والتكامل بين نصفي الدماغ. خطوات الحصص في البرنامسج: وتتم حصص البرنـامج وفق الخطوات التالية: التهيئة واثارة الاهتمـام، اكتسـاب الخبرات الجديدة، التفصـيل وتعميق الفهم (تطبيق المعرفـة)، تجسير وتأصسيل التعلم وتعميق المعالجـات الدماغية (انتقال أثر التعلم)، التقويم، فالتلخيص. الاستر اتيجيات المستخدمة في البرنامج: استخدم البرنـامج الاستراتيجيات التالية لملاءمتها طبيعـة القراءة وطبيعـة الفئسة المستهدفة ولإمكانية تطبيقها في الأساليب التدريسية، ولاستنادها على جانبي الدماغ وهي: جلدول (§) الاستراتيجيات المستخلمة في البرنامج

\begin{tabular}{|c|c|c|c|}
\hline الإجــــــراء & الجانب الائيسر & الإجــــــراء & الجانب الأيمين \\
\hline تحليل الكلمات لمقاطع او حروف & 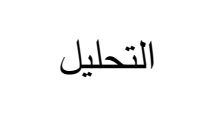 & 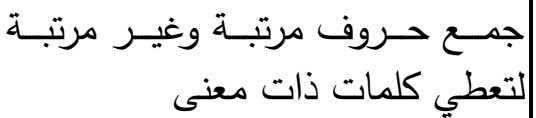 & التركيب \\
\hline سرد قصة واقعية & 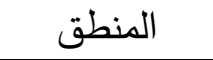 & سرد قصة من الخيال & 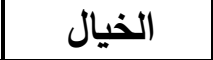 \\
\hline استثارة التلميذة لتستخلص المطلوب & الاستتتاج & |ستثارة الإجابات والتوقعات & التخمين الت \\
\hline التلميذة & التعليمات المحددة & 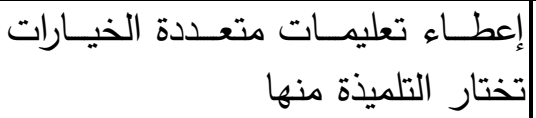 & التعليمات الحرة \\
\hline المادة الماضـرة والإلقـاء الشفوي لعرض & الثرح اللفظي & |التجريب العملي إلـى المعلومــة مـن خـلال & التجريب \\
\hline تحديد وقت الإجابة بزمن محدد & إدراك الوقت & إعادة صياغة المعلومة بنشيد يلحن & الالحان \\
\hline
\end{tabular}

الفئستة المستهدفتة في البرناهـج:

ذوات صعوبات القراءة في مستوى التعرف على الكلمة في الصف الثالث الابتدائي في مدينة الطائف، واختارت الباحثان الصف الثالث الابتدائي لكونهن وصلن إلى مرحلة من المفترض أن يكون لديهن مستوى التعرف على الكلمة متقن ويتم تطبيق البرنامج لعلاج صعوبة القراءة لديهن. 
تم الاعتمـاد فيها على مهارات ومعايير وأهداف وزارة التعليم التي تتحصـر في مهارات التعـرف على الكلمـة. والاختبـار التشخيصـي (اختبـار التعـرف على الكلمـة) يماثل الاختبـارات التشخيصية للمعلمين والمتضمن على الفقرات التي تختص باختبار القراءة مستوى التعرف على

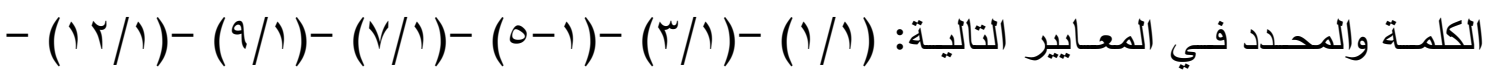

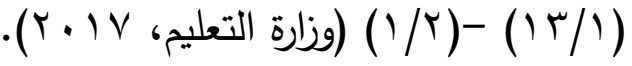 المـدة الـزمنيـة للبرنامسج:}

تم تقديم البرنـامج بواقع اثتتين وعشرين حصـة (ثلاث حصص اسبوعيًا) موزعة على ستة أهداف قصيرة المدى، وهي الأهداف من واحد إلى ستة، وتنبثق من الأهداف قصيرة المدى الستة المستهدفة في البرنامج، خمسة عشر هدفًا تدريسًا لكل هدف تدريسي حصسة مدتها خمس وأربعون دقيقة وست حصص لمراجعة الأهداف قصيرة المدى، وحصة في بداية اللقاء تكون تعريفية، وبناء ألفة، ومراجعة للمتطلبات السابقة المطلوبة للبرنامج، وتتحصر في مهارات التعرف على الحروف الهجائية كاملة بأشكالها المختلفة وأصواتها القصيرة والطويلة والساكنة.

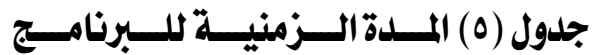

\begin{tabular}{|c|c|}
\hline المـــــــلة & الأهــــــــــاف \\
\hline م بواقع حصة واحدة & الحصة التعريفية \\
\hline 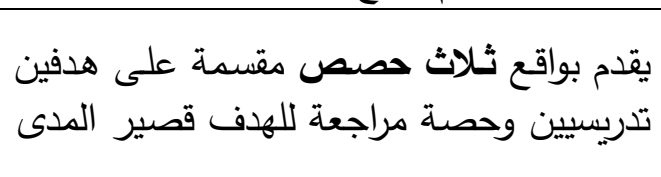 & 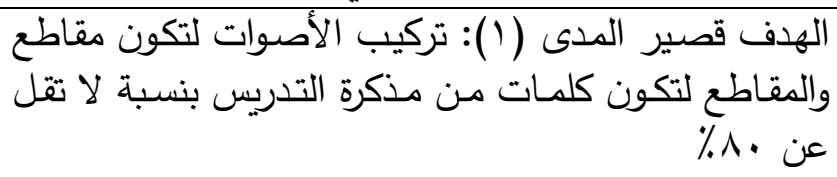 \\
\hline تدريسيين وحصاقع ثلاث حصاجعة مقلهدف قصدير على هدفين المدى & 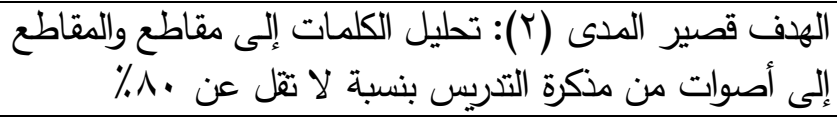 \\
\hline تدريسيين وحصاقع ثلاثة حصاجعة للهدف مقسمة عصى هدفين المدى & 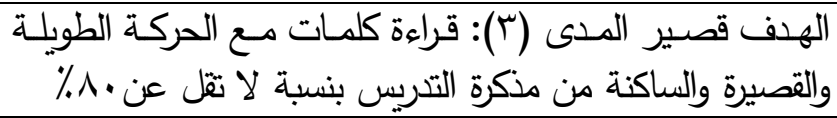 \\
\hline 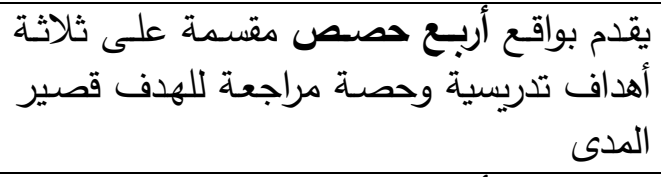 & 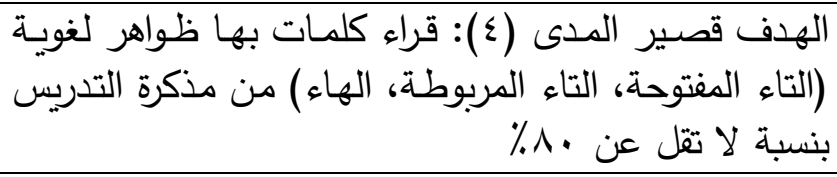 \\
\hline 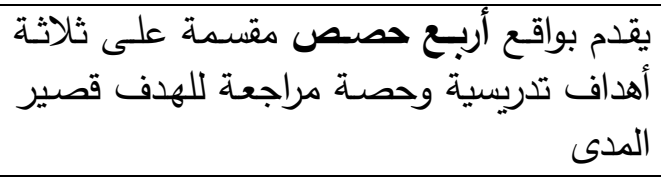 & 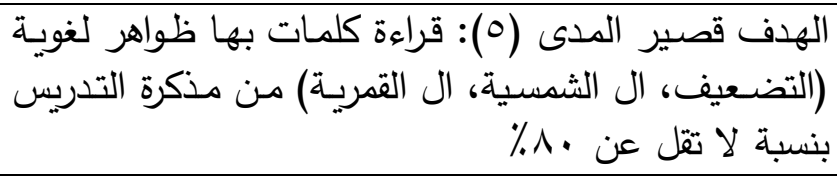 \\
\hline 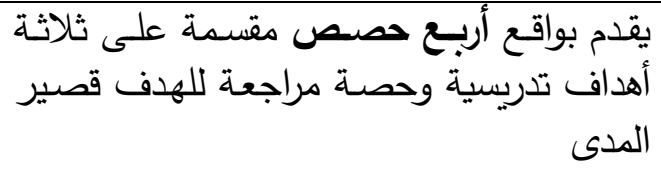 & 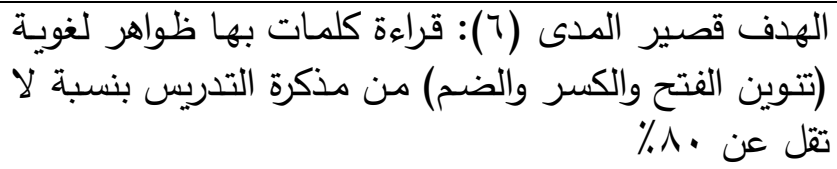 \\
\hline
\end{tabular}




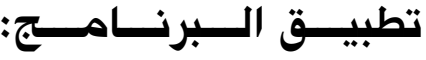

تم تطبيق البرنامج على العينـة التجريبية المكونـة من ثمانيـة تلميذات من الصف الثالث الابتدائي ذوات صعوبات القراءة في المدارس الحكومية التي تتضمن برامج صعوبات تعلم وذلك بواقع: تلميذتين في الابتدائية الثالثة، وثلاثة تلميذات بالابتدائية الخامسـة عشرة، وثلاثة تلميذات بالابتدائية العشرون، وذلك بالتعاون مع معلمات صعوبات التعلم اللواتي تم تدريبهن على البرنامج والتواصل معهن طوال فترة التطبيق على العينة التجريبية والاستفادة من ملاحظاتهن، وتم التطبيق في الفصل الدراسي الأول لعام (§£ (اهـ ولقصر الترم تم إضـافة حصـة كل أسبوع بحيث تصبح أربعة حصص أسبوعيًا بدلًا من ثلاثة.

تتلخص إجراءات البحث بشكل مختصر في التالي:

تحديد مشكلة البحث ووضع خطة.

الاطلاع على الأدب النظري والدراسات السابقة.

إعداد أدوات البحث المكونة من: اختبار القراءة، ومقياس أنماط التعلم والتفكير، والبرنامج

القائم على أنماط التعلم والتفكير لخفض حدة صعوبات القراءة.

$$
\text { التحقق من صدق وثبات أدوات البحث. }
$$

تحديد مجتمع وعينة البحث.

تطبيق أدوات البحث مـن خـلال التطبيق القبلي لاختبار القراءة، ومقيـاس أنمـاط التعلم والتفكير ، واختبار رسم الرجل للذكاء، على العينة التجريبية والضابطة.

تطبيق البرنـامج القـائم على أنماط التعلم والتفكير لخفض صسوبات القراءة على العينـة التجريبية فقط.

تطبيق أدوات البحث مـن خلال التطبيق البعدي لاختبار القراءة، ومقيـاس أنماط التعلم والتفكير، على العينة التجريبية والضابطة.

تطبيق أدوات البحث من خـلال التطبيق التتبعي لاختبار القراءة، ومقياس أنماط التعلم والتفكير، على العينة التجريبية بعد شهر من التطبيق البعدي. تحليل بيانات التطبيق واستخلاص النتائج. 
• اختبار ويلكوكسون(W) ومان ويتني (U) ل طريقة التجزئة النصفية، وألفا كرونباخ. المتوسط الحسابي. ومعامل ارتباط بيرسون، وسبيرمان-براون، وجاتمان.

\section{نتسائسج ج البحسث وهنساقشتهـا:}

\section{نتائج الفرض الأول والذي ينص على:}

توجد فروق دالة إحصائياً بين درجات المجموعة الضابطة والمجموعة التجريبية في اختبار

القراءة البعدي لصالح المجموعة التجريبية.

ولاختبار صحة هذا الفرض تم استخدام اختبار مان-ويتني (U) لدلالة الفروق بين رتب

درجات المجموعات الصغيرة والمستقلة وكانت النتائج كما في الجدول التالي: جلدول ( (7) الفروق بين المجموعة الضابطة والمجموعة التجريبية في اختبار القراءة البعدي

\begin{tabular}{|c|c|c|c|c|c|c|}
\hline مستوى الدلالة & قيمة Z & قيمة (U) & متوسط الرتب & المتوسط & المجموعة & الاختبار \\
\hline \multirow{2}{*}{$\cdots 9$} & \multirow{2}{*}{$r, T \cdot \varepsilon$} & \multirow{2}{*}{$\vee, 0 \ldots$} & 11,07 & $\Lambda$, rVo. & التجريبية & \multirow{2}{*}{ اختبار القراءة } \\
\hline & & & $0, \Sigma \varepsilon$ & $\varepsilon, \ldots$ & الضابطة & \\
\hline
\end{tabular}

ومن العرض السابق يتضـح أن هنالك فروق دالة إحصائيًا حيث إن مستوى الدلالة 009.

وهي أقل من 05. مما يعني أنه توجد فروق وبالتالي نقبل الفرض البديل الذي ينص على (توجد فروق دالة إحصائياً بين درجات الدجمعة الضابطة والمجموعة التجريبية في درجات اختبار القراءة البعدي لصـالح المجموعـة التجريبية)، ويؤكد متوسط درجـات المجموعتين أن هنـالك فروق دالـة لصـالح المجموعـة التجريبية حيث نجد أن متوسط المجموعـة التجريبية = 8.375 بينمـا متوسط درجات المجموعة الضابطة =4.0.

وتعزو الباحثان الفروق بين المجموعتين الضابطة والتجريبية إلى البرنامج القائم على أنماط

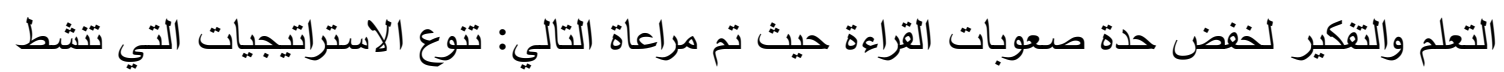


الجانب الأيمن والأيسر والجانبين معًا من الدماغ، وتتوع طرق التعزيز واعتمادهـا على اختيار

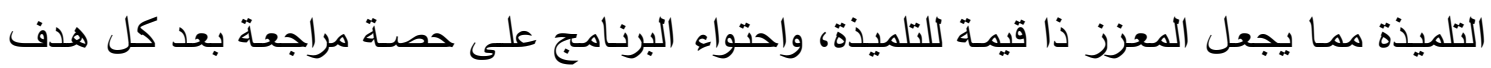
قصير الددى، وتتوع الأنشطة والتدريبات بحيث تقلل من الملل وتزيد من الدافعية للتعلم، ومراعاة

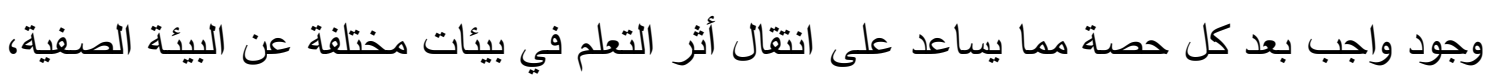

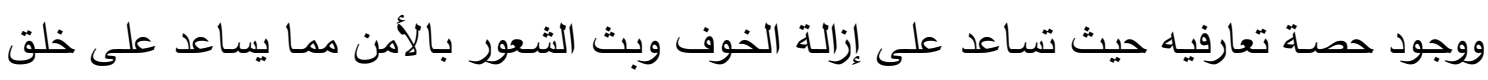

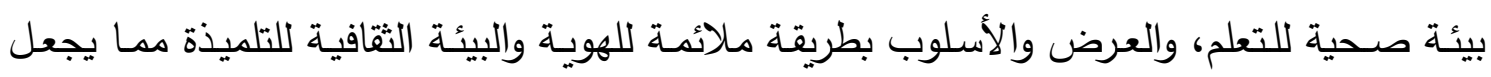
التعلم ذا معنى وقريب من مفاهيم التلميذات.

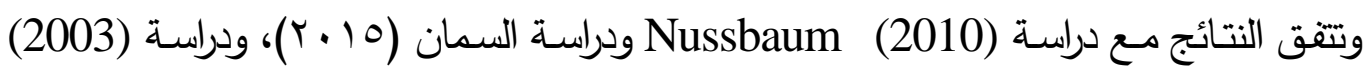

.Blachman, et. Al. (2004) ودراسة Aylward, et.al. (2003) ودراسة (Shaywitz, et. Al.

\section{نتائج الفرض الثاني والذي ينص على:}

لا توجد فروق دالة إحصائياً بين درجات القياس القبلي والبعدي في مقياس أنماط التعلم

والتنكير لاى المجموعة التجريبية.

ولاختبار صحة هذا الفرض تم استخدام اختبار ويلكوكسون ويتفرع من الفرضية السابقة

ثلاث جوانب (الأيمن والأيسر والمتكامل) والنتائج كما في التالي:

جلول (v) الفروق بين درجات القياس القبلي والبعلي في مقياس أنماط التعلم والتفكير للى المجموعة التجريبية.

\begin{tabular}{|c|c|c|c|c|c|c|}
\hline مستوى الدلالة & $\mathbf{z}$ & مجموع الرتب & متوسط الرتب & ن & اتجاه القياس & المتفـــيرات \\
\hline \multirow{4}{*}{. T纟. } & \multirow{4}{*}{$r, 11 \mathrm{~V}$} & $r 7,0$ & $\varepsilon, \varepsilon Y$ & 7 & الرتب السالبة & \multirow{4}{*}{ 1-النمط الأيمن } \\
\hline & & $1,0$. & $1,0$. & 1 & الرتب الموجبة & \\
\hline & & & & 1 & الرتب المتساوية & \\
\hline & & & & $\Lambda$ & المجموع & \\
\hline \multirow{4}{*}{$. r)$. } & \multirow{4}{*}{$r, r, T$} & $r \leqslant, 0$ & $\varepsilon, 9 \pi$ & V & الرتب السالبة & \multirow{4}{*}{ ץ-النمط الأيسر } \\
\hline & & $1,0$. & $1,0$. & 1 & الرتب الموجبة & \\
\hline & & & & . & الرتب المتساوية & \\
\hline & & & & $\wedge$ & المجموع & \\
\hline \multirow{4}{*}{$.1 r}$. & \multirow{4}{*}{ T,OY } & $\cdots$ & $\cdots$ & - & الرتب السالبة & \multirow{4}{*}{ r-النمط المتكامل } \\
\hline & & rq, & $\varepsilon, 0$. & 1 & الرتب الموجبة & \\
\hline & & & & - & الرتب المتساوية & \\
\hline & & & & $\Lambda$ & المجموع & \\
\hline
\end{tabular}


ومن العرض السابق يتضـح أن النتائج دالة إحصـائيًا مما يجعلنا نرفض الفرض الصفري الذي ينص على أن (لا توجد فروق دالة إحصائياً بين درجات القياس القبلي والبعدي في مقياس أنماط التعلم والتفكير لدى المجموعة التجريبية) ونقبل الفرض البديل الذي ينص (توجد فروق دالة إحصائياً بين درجات القياس القبلي والبعدي في مقياس أنماط التعلم والتفكير لدى المجموعة التجريبية حيث تتركز الدرجات في أحد الجانبين في القياس القبلي وتتوزع بشكل متقارب بين الجانب الأيمن والأيسر والمتكامل في القياس البعدي) وتعزو الباحثان الفـروق إلى البرنـامج القـائم على أنمـاط التعلم والتفكير وذلك لاحتوائسه على اسـتراتيجيات متتوعـة تهـدف إلـى تنثـيط جـانبي الــدماغ، وتتفـق النتـائج مـع دراســة . Nussbaum و و و (2010) Sylward, et al. (2003) Shaywitz, et al. (2003)

\section{نتائج الفرض الثالث والذي ينص على:}

لا توجد فروق دالة إحصائياً في درجات القياس البعدي في مقياس أنماط التعلم والتنكير

بين المجموعة التجريبية والضابطة.

ولاختبار صـحة هذا الفرض تم استخدام اختبار مـان -ويتتي (U) ويتفرع من الفرضية

السابقة ثلاث جوانب (الأيمن والأيسر والمتكامل) والنتائج كما في التالي:

جدول (^) الفروق في درجات القياس البعدي في مقياس أنماط التعلموالتفكير بين المجموعة التجريبية والضابطة

\begin{tabular}{|c|c|c|c|c|c|c|}
\hline مستوى الدلالة & قيمة & قيمة (U) & متوسط الرتب & المتوسط & المجموعة & الجانب \\
\hline \multirow{2}{*}{..r. } & \multirow{2}{*}{$r, 17 V$} & \multirow{2}{*}{$r, \ldots$} & $\varepsilon, V_{0}$ & $I Y, \wedge \vee 0$ & التجريبية & \multirow{2}{*}{ الأيمن } \\
\hline & & & Ir, ro & $r r, 0 .$. & الضابطة & \\
\hline \multirow{2}{*}{ 人тะ. } & \multirow{2}{*}{101.} & \multirow{2}{*}{$r \cdot, 0 \ldots$} & 1,79 & $1 \varepsilon, Y_{0}$. & التجريبية & \multirow{2}{*}{ الأيسر } \\
\hline & & & $\lambda, r_{1}$ & $1 \varepsilon, \ldots$ & الضابطة & \\
\hline \multirow{2}{*}{..1. } & \multirow{2}{*}{$r, \varepsilon 19$} & \multirow{2}{*}{$\cdots$} & $1 Y, 0$. & $1 \cdot, \wedge \vee 0$ & التجريبية & \multirow{2}{*}{ متكامل } \\
\hline & & & $\varepsilon, 0$. & $0 \ldots$ & الضابطة & \\
\hline
\end{tabular}




\section{وفيما يلي تفسير النتائج للثلاث جوانب (الأيمن، والأيسر ، والمتكامل):

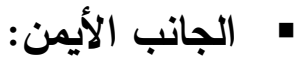

هناك فروق دالة إحصـائياً حيث مستوى الدلالـة 002. وهي أقل من 05. ممـا يعني أن هناك فروق دالة وبالتالي نرفض الفرض الصفري الذي ينص على (لا توجد فروق دالة إحصائياً في درجات القياس البعدي لمقياس أنماط التعلم والتفكير بين المجموعة التجريبية والضـابطة) وتقبل الفرض البديل الذي ينص على (توجد فروق دالة إحصائياً في درجات القياس البعدي لمقياس أنمـاط التعلم والتفكير بين المجموعة التجريبية والضـابطة في الجانب الأيمن لصـالح المجموعـة الضـابطة)، ومن درجة المتوسط يتضح أن الفروق لصـالح المجموعة الضـابطة حيث أن متوسط درجات المجموعة التجريبية 12.875 في حين أن متوسط درجات المجموعة الضـابطة 23.5 ، 2.5 وهذا يدل على أن المجموعة الضابطة كانت درجاتها مرتفعة في الاعتماد على الجانب الأيمن من الدماغ، وهذا ما يفسر صعوبة القراءة كما في دراسة (Shannon \& rice, 1982)، ودراسة

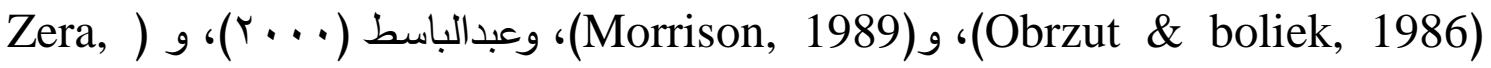

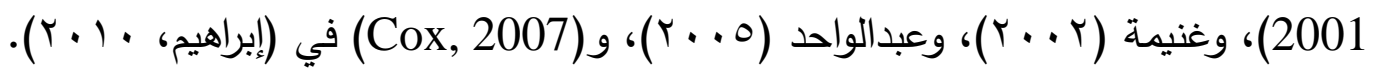

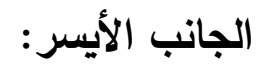

ومن الجدول السـابق يتضـح أن قيمة u uير دالـة إحصـائيًا =864. مما يعني أننـا نقبل الفرضية الصفرية التي تتص على (لا توجد فروق دالة إحصائياً في درجات القياس البعدي لدقياس أنــاط التعلم والتفكير بين المجموعة التجريبية والضـابطة)، ومتوسط الدرجات بين المجموعتين متقارب حيث أن متوسط درجات المجموعة التجريبية= 14.25 أما الضابطة= 14.

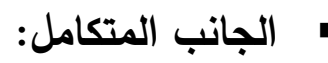

هناك فروق دالة إحصـائيًا حيث أن مستوى الدلالمة = 001. وهي أصـغر من 05. ممـا يجعلنا نرفض الفرض الصفري الذي ينص على (لا توجد فروق دالة إحصائياً في درجات القياس البعدي لمقياس أنماط التعلم والتفكير بين المجموعة التجريبية والضابطة) ونقبل الفرض البديل الذي لني ينص على (توجد فروق دالة إحصائياً في درجات القياس البعدي لمقياس أنماط التعلم والتفكير بين 
المجموعة التجريبية والضابطة في الجانب المتكامل لصالح المجموعة التجريبية) ، كما أن متوسط درجات المجموعة التجريبية = 10.875 أما الضـابطة = 5. وهو فرق بين المتوسطين مما يدل على أن المجموعة التجريبية التي تم تطبيق البرنامج القائم على أنماط التعلم والتنكير كانت تعتمد بدرجة أكبر على الجانب المتكامل وهو يساعد على تعلم القراءة وتخفيف الصعوبات كما في دراسة Gladstone, et. Al. (1989)، والاعتماد على الجانب المتكامل يعد من أهداف البحث.

\section{نتائج الفرض الرابع والذي ينص على:}

توجد فروق دالة إحصائياً بين درجات القياس القبلي والقياس البعدي في اختبار القراءة

$$
\text { لاى المجموعة التجريبية لصالح الاختبار البعدي. }
$$

ولاختبار صحة هذا الفرض تم استخدام اختبار ويلكوكسون وكانت النتائج كما في الجدول التالي:

جدول (9) الفروق بين درجات القياس القبلي والقياس البعدي في اختبار القراءة لدى المجموعة التجريبية

\begin{tabular}{|c|c|c|c|c|c|c|}
\hline مستوى الدلالة & $\mathbf{z}$ & مجموع الرتب & متوسط الرتب & ن ن & اتجاه القياس & المتفــيرات \\
\hline \multirow{4}{*}{$.1 Y}$. & \multirow{4}{*}{ T,OYE } & $\cdots$ & $\cdots$ & . & الرتب السالبة & \multirow{4}{*}{ اختبار القراءة } \\
\hline & & rч,. & $\varepsilon, 0$. & $\wedge$ & الرتب الموجبة & \\
\hline & & & & · & الرتب المتساوية & \\
\hline & & & & $\wedge$ & المجموع & \\
\hline
\end{tabular}

يتضـح من الجدول أن النتائج دالة إحصـائيًا حيث إن مستوى الدلالـة يساوي 012. ممـا يجعلنا نرفض الفرض الصفري الذي ينص على (لا توجد فروق دالة إحصائياً بين درجات القياس القبلي والقياس البعدي في اختبار القراءة لدى المجموعة التجريبية لصالح القياس البعدي) ونقبل الفرض البديل الذي ينص على (توجد فروق دالة إحصائياً بين درجات القياس القبلي والقياس البعدي في اختبار القراءة لاى المجموعة التجريبية لصالح القياس البعدي)، وتعزو الباحثان الفروق لتروي في اختبار القراءة البعدي إلى البرنامج القائم على أنماط التعلم والتفكير حيث تم مراعاة أن ذوي صعوبات التعلم لديهم مشكلة في السيطرة الدماغية مما يؤدي لصعوبات تعليمية كما في دراسة

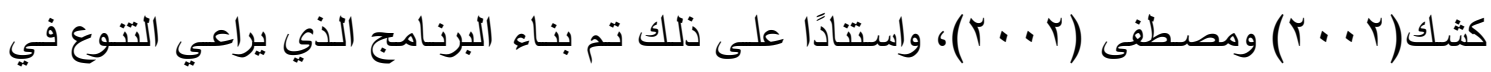


تتشيط جوانب الدماغ، وأثبتت الدراسـات أن الطلبة ذوي صسوبات التعلم ينجزون بشكل أفضل عندما يتعلمون بالتركيز على أساليب تعليمهم (عيسى وخليفة، V . . Y، Y • ( ).

\section{نتائج الفرض الخاهس والذي ينص على:}

لا توجد فروق دالة إحصـائياً بين درجات القياس البعدي والتتبعي لاختبار القراءة لدى

المجموعة التجريبية.

وللتحقق من صحة هذا القرض تم استخدام اختبار ويلكوكسون وكانت النتائج كما في الجدول:

جدول (•1) الفروق بين درجات القياس البعدي والتتبعي لاختبار القراءة لدى المجموعة التجريبية

\begin{tabular}{|c|c|c|c|c|c|c|}
\hline مستوى الدلالة & $\mathbf{z}$ & مجموع الرتب & متوسط الرتب & ن & اتجاه القياس & المتفــــرات \\
\hline \multirow{4}{*}{ 1.r. } & \multirow{4}{*}{ איזר, 1 } & $1,0$. & $1,0$. & 1 & الرتب السالبة & \multirow{4}{*}{ اختبار القراءة } \\
\hline & & $1 \Gamma, 0$ & ץ, « & $\varepsilon$ & الرتب الموجبة & \\
\hline & & & & r & الرتب المتساوية & \\
\hline & & & & $\wedge$ & المجموع & \\
\hline
\end{tabular}

ومن العرض السابق يتضح أن النتائج غير داله إحصائيًا حيث إن مستوى الدلالة =102.

وهذا يجعلنا نقبل الفرض الصفري الذي ينص على أن (لا توجد فروق دالة إحصائياً بين درجات القياس البعدي والتتبعي لاختبار القراءة لدى المجموعة التجريبية)، وتعزو الباحثان استمرارية أثر البرنامج إلى الاستراتيجيات المتنوعة التي تتشط كافة جوانب الدماغ، وإلى اتباع البرنامج الخطوات التدريسية من خـلال التهيئة وإثارة الاهتمام، ثم اكتساب الخبرة الجديدة وفقًا لجانبي الدماغ، ثم التفصيل وتعديق الفهم (تطبيق المعرفة) لجانبي الدماغ، ثم تجسير وانتقال التعلم الدكتسب وتعزيز جانبي الدماغ، ثم التلخيص، ثم التقويم، وأيضـا الثـعور بالرضـا والثقـة عند القدرة على قراءة الكلمات. وتتقق نتيجة هذا الفرض مع دراسة Marshall (2018) و Geary (2013) Heyman .(2014) Kaya و (2011) 


\section{التـــوصيسـات:}

في ضوء الأدب النظري والدراسات السابقة ونتائج البحث الحالي، تستخلص الباحثان أهم

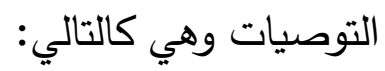

هادراج أنماط التعلم والتنكير بدليل المعلم كأحد الاستراتيجيات المستخدمة مع ذوي صعوبات التعلم عموماً وذوي صعوبة القراءة بالأخص، وتدريب المعلمات عليها من خـلال عقد

$$
\text { الدورات التدريبية. }
$$

إعادة النظر في صياغة منهج القراءة، والتتويع في الاستراتيجيات بحيث تتشط كافة جوانب الدماغ، وتتماشى مع كافة أنماط التعلم والتفكير. تقديم بـرامج إرشـادية لأولياء الأمسور بكيفيـة التعامل مـع أبنـاءهم ذوي صـوبات التعلم، وتتمية نمطهم في التعلم والتثكير ، وتتشيط الأنماط الغير نثطة.

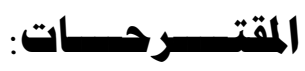

في ضوء ما توصلت إليه الدراسة الحالية يمكن اقتراح إجراء الدراسات التالية: إجراء المزيد من الدراسات لنفس موضوع البحث الحالي على عينات مختلفة من صفوف عدة، وصعوبات أخرى، وفي بيئات جديدة. إجراء دراسات وصفية لحصر نسب انتشار أي من أنماط التعلم والتنكير ، لاى العاديين وذوي صسوبات التعلم، وتحليل المنـاهج وتصنيف استخدام استراتيجياتها لتنشيط أنماط

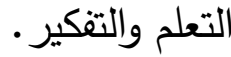




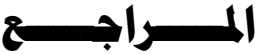

\section{أولاً: المسراجـه العــربيستة:}

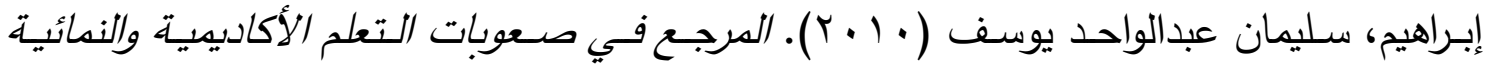
والاجتماعية والانفعالية. القاهرة: مكتبة الأنجلو المصرية.

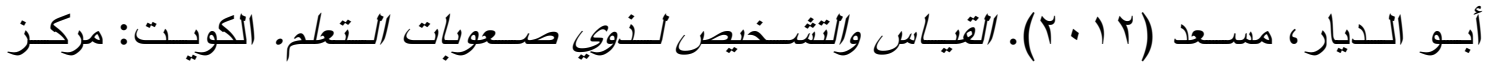
تقويم وتعليم الطفل.

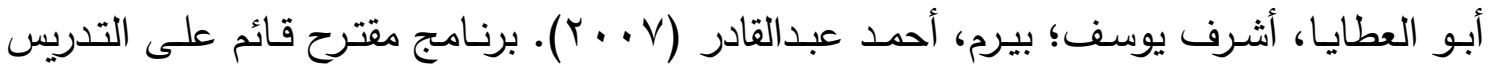
لجانبي الدماغ لتتمية الجوانب المعرفية في العلوم لدى طلاب الصف التاسع. الجمعية

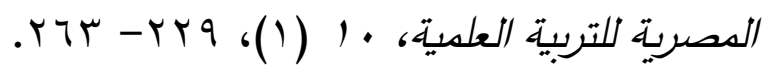

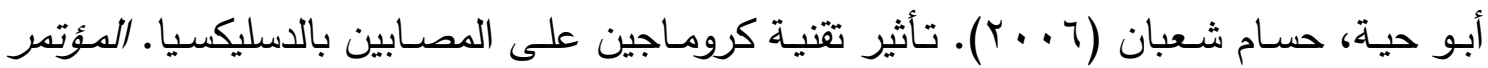
الدولي لصعوبات التعلم، الرياض: المملكة العربية السعودية.

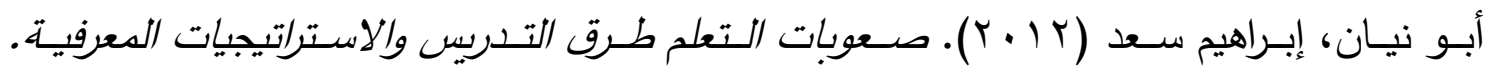
السعودية: دار الناشر الدولي للتشر والتوزيع.

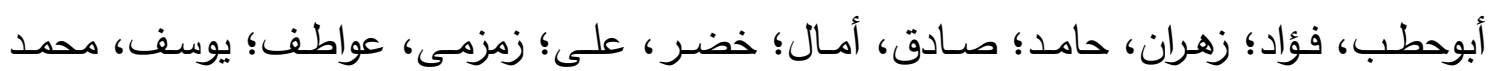
جميل؛ وقاد، إلهام؛ موسى، عبدالله عبدالحى؛ محمود، يوسف؛ بدر ، فائقة (9V9 (1). تقننين اختبار سم الرجل على البيئة السعودية الدنطقة الغربية. مركز البحوث التربوية والنفسية، كلية التربية، جامعة الملك عبدالعزيز • أحمد، عبير طوسون (T ( • Y). فاعلية برنامح تدريبي لتحسين مستوى الوعي الفونولوجي وأثره على تحسين مستوى القراءة لدى التلاميذ ذوي صعوبات القراءة. مجلة الإشاد النغسي، (0؛)،

$$
\text { يناير ، }
$$

آدم، مرفت محمد كمال (1 ( • ( ). فعالية استراتيجية مقترحة في ضوء نظريـة التعلم المستتد إلى جانبي الدماغ على التحصيل ومهارات التفكير البصـري والكفـاءة الذاتيـة الددركـة للدى

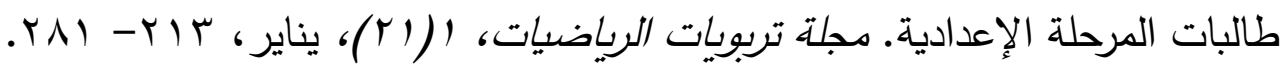




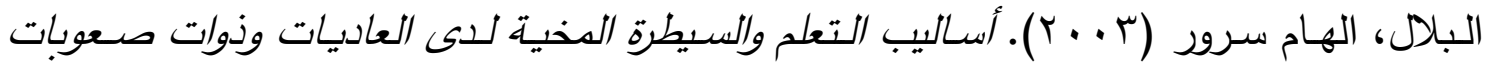
التعلم من تلميذات المرحلة الابتدائية. رسالة دكتوراة (غير منشورة). الرياض: كلية التربية.

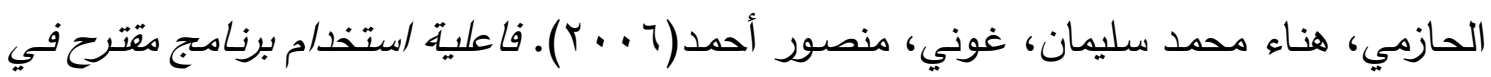
تندية ندط تعلم النصف الكروي الأيدن للدماغ لدى طالبات العلوم بالمرحلة المتوسطة بالمدينة المنورة. رسالة ماجستير، جامعة طيية، كلية التربية والعلوم الانسانية. الديب، محمد مصطفى ( . . ب). الفروق بين ذوي صعوبات التعلم والعاديين في بعض السمات

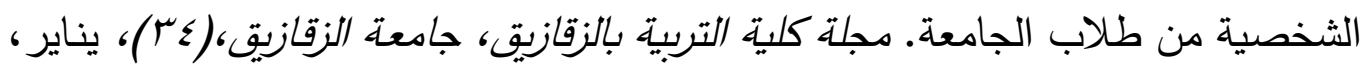
RTV $-I V T$

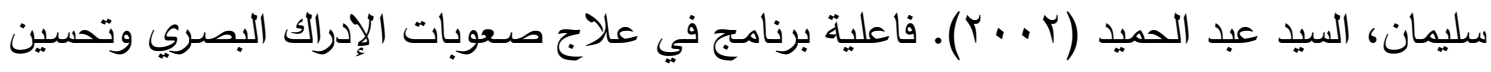
مستوى القراءة لدى الأطفال ذوي صعوبات التعلم. مجلة دراسات تربوية واجتماعية، كلية التربية، مصر : جامعة حلوان. السمان، مروان أحمد محمد (10 ب). برنامج قائم على نظرية التعلم المستند إلى الدماغ لعلاج

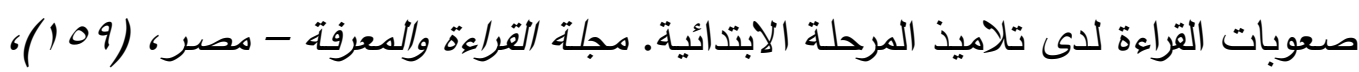

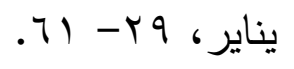
الثلي، خالد (11 + r). الدسليكسيا في المدرسة الابتدائية المغربية: واقع غير معروف عند أغلب

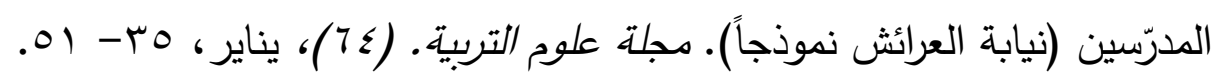

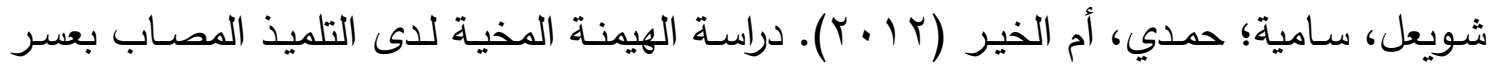
القراءة (الدسلكسيا) بمنطقة تمنراست " تتاول نفس عصبي. مجلة العلوم الانسانية، (N (r)،

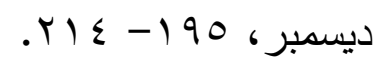

صباح، شيدي (1) (Y). دافعية الإنجاز وعلاقتها بعسر القراءة لدى عينة من المرحلة الابتدئية. رسالة الماجستير، الجزائر : جامعة قسطنطينة. عبدالحفيظ، شـلابي، وعلي، مشرط (Y V V V). تصسيم اختبار لتشخيص عسر القـراءة لأطفال المرحلة الابتدائية. رسالة دكتوراة، الجزائر : جامعة ابي بكر بلقايد- تلمسان، كلية العلوم

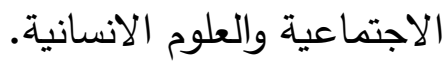




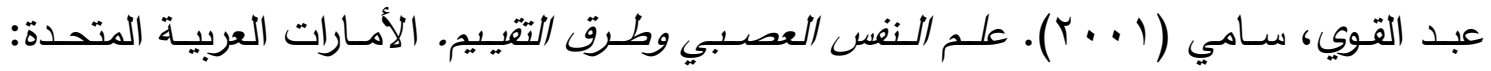
مطبوعات جامعة الأمارات العربية المتحدة.

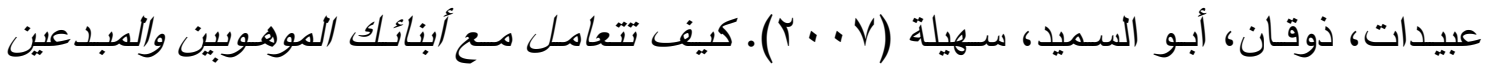
والمتفقوقين؟. الرياض: مكتب التربية للخليج العربي.

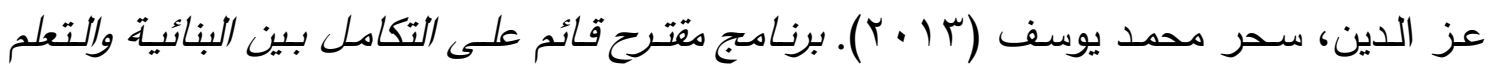
المستند للدماغ لتنمية مهارات ما وراء المعرفتة في الاستقصاء المعدلي في العلوم لدى

طلاب كلية التربية. رسالة دكتوراه، كلية التربية، جامعة بنها.

عفانة، عزو، والجيش، يوسف (T ( • r). أثر استخدام استراتيجية التعليم بالدماغ ني الجانبين في تدريس العلوم لتنمية بعض عادات العقل المنتج لدى طالبات الصف التاسع الأساسي بغزة.

رسالة ماجستير ، غزة: الجامعة الاسلامية.

عقل، محمود بدر ( 99 ( ). الأساسيات في تشريح الإنسان. عمان: دار الفكر للنشر . عيد، أيمن رجب محمد (9 . r). برنامج مقترح قائم على جانبي الدماغ لتنمية بعض مهارات التفكير في الرباضيات للى طلاب الصف الخامس الأساسي بغزة. رسالة ماجستير، كلية

التربية، الجامعة الإسلامية، غزة.

عيسى، مراد؛ علي، خليفة؛ وليد سيد ( V . . . . كيف يتعلم المخخ ذو صعوبات الكتابة والعسر الكتابي. طا ، الإسكندرية: دار الوفاء لدنيا الطباعة والنشر .

عيسى، جابر محمد عبدالله أبوزيد، أحمد محمد جاد الرب ( Y I . ) ). أنماط اللعب مع الأقران والطلاقـة اللفظية كمنبئات بالقدرات الإبتكاريـة لدى أطفال الروضــة الموهوبين والعـاديين.

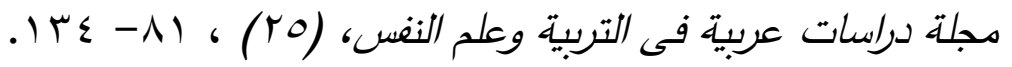

الفرا، إسماعيل صـالح (T ( • r). صعوبات تعلم القراءة وتشخيصها وأساليب ملاحظتها ومعالجتها وفق آراء معلمي المرحلة الأساسية( (-7). مجلة IUG للعلوم التربوبية والنفسية (الجامعتة

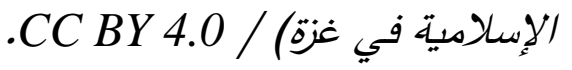

كثك، رضا عبد الستار (r . . . ). فعالية برنامج إشادي في خفض حدة النشاط الزائد لدى أطفال الروضة. مصر : رسالة ماجستير غير منشورة، كلية التربية، جامعة الزقازيق. 


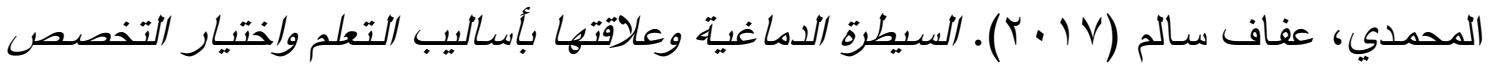

والمستوى الدراسي لدى طالبات الجامعة. السعودية: جامعة الملك سعود، كلية التربية.

محمود، أميرة عبدالمنعم محمد و شوكت، عواطف إبراهيم أحمد وحموده، محمود عبدالرحمن، سليمان، سناء محمد (Y V r Y). فعالية برنامج للنصف الأيمن من المـخ لعلاج صعوبات

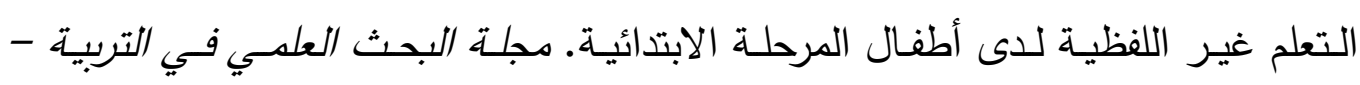

$$
\text { مصر، T) }
$$

مراد، صلاح أحمد (؟9 9 (). تقنين مقياس أنماط التعلم والتفكير • مجلة كلية التربية، كلية التربية،

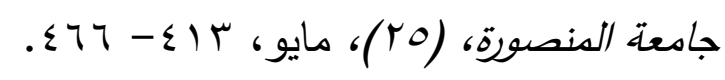

مـراد، صـلاح أحمد، و أحمد، محمد عـامر (1) (ب). أنمـاط التعلم والتفكير وعلاقتها بالتفـاؤل والتثـاؤم لطلبة التخصصـات التكنولوجيـة. القـاهرة : المجلـة الدصـية للدراسـات النفسية،

$$
\text { . } 1-11 \text { 1 } 11
$$

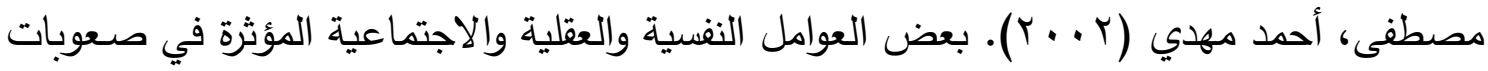

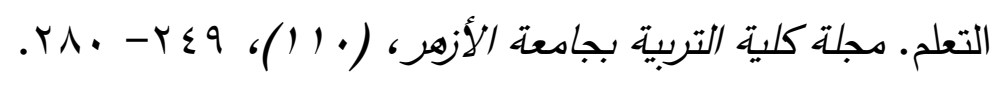

وزارة التعليم (10 • ب). دليل معلم/ معلدة صعوبات التعلم. السعودية: وكالة الوزارة للتعليم، الإدارة العامة للتزبية الخاصة، إدارة صعوبات التعلم. وزارة التعليم (V ا • Y أ) ـ الاختبارات التشخيصية لذوي صعوبات التعلم في مادتي اللغتة العربية والرياضيات بالمرحلة الابتدائية. السعودية.

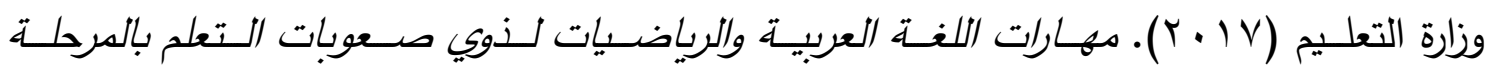
الابتدائية. السعودية.

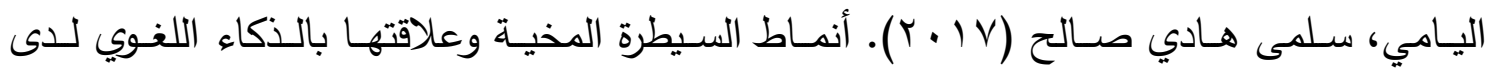
المعسرين قرائياً. عالم التربية، ( (.7)، المؤسسة العلمية للاستشارات العلمية وتتمية الموارد

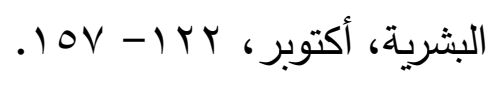




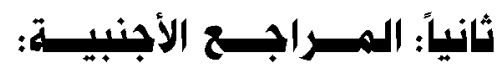

American Psychological Association (2015). APA Dictionary (2nd ed).

Washington: American Psychological Association.

Aylward, E.H., Richards, T.L., Berninger, V.W., Nagy, W.E., Field, K.M., \& Grimme, A.C. (2003). Instructional treatment associated with changes in brain activation in children with dyslexia. Neurology, 61, 212-219.

Blachman, B.A., Schatschneider, C., Fletcher, J.M., Francis, D.J., Clonan, S.M., \& Shaywitz, (2004). Effects of intensive reading remediation for second and third graders and a 1-year follow-up. Journal of Educational Psychology, 96, 444-461.

Dimitriadis, S. I., Simos, P.G., Fletcher, J. M., \& Papanicolaou, A. C.(2018) Aberrant resting-state functional brain networks in dyslexia: Symbolic mutual information analysis of neuromagnetic signals. International Journal of Psychophysiology 126, 20-29.

Faramarzi, S. Abedi, A. \& Ghamarani, A. (2019). Designing the Comprehensive Diagnostic Test of Dyslexia (CDTD) and Investigating its Validity and Reliability for Primary School Students of Isfahan in 2015-2016. Journal of Paramedical Sciences \& Rehabilitation 8(2), 17-28.

Geary, D. (2013). The Effect of Brain-Based Learning Approach on Students, Attitudes Toward Mathematics. e- Journal of New World Sciences Academy, 4(3),779-796.

Gladstone, M., Best, C.T., \& Davidson, R.J. (1989). Anomalous Bimanual Coordination Among Dyslexic Boys. New York: Haskins Laboratories. 
Heyman, W. (2011). The effect of brain based learning on academic success, attitude and retrieval of information in science and technology classes. Lyon, France: In ESERA conference September/ 5-9.

Harold, N. (2019). The Self-Diagnostic Test: Evaluating Patients and Theories. Feeling Smarter and Smarter, 55-61.

Kaya, O. (2014). The Effects Brain-Based Learning Strategy on Mathematics Achievement. Journal of Learning Disabilities,33,168-179

Marshall, S.(2018). The Effects Brain-Based Learning Strategy to developing some mathematical strength skills, Immediate and delayed achievement in mathematics and attitudes towards it, In the ninth grade students with learning disabilities in mathematics. Journal of learning disabilities. 36(5),437-479.

Mehrdad, A.G., \& Ahghar, M. (2011). Learning styles and learning strategies of left-handed EFL students. Procedia - Social and Behavioral Sciences,(31) $536-545$.

Nussbaum,S.S. (2010). The effects of "Brain Gym" as a general education intervention improving Academic performance and behavior, PHD, Northcentral university, prescott valley, Arizona.

Nuyts, E. (2012). Dyslexia, dyscalculia, prevention et remedies, $2^{\text {nd }}$. Paris :Edition.

Peters, L., Bulthé, J.C., Daniels, N., Beck, H.O., \& Smiedt, B.D. (2018). Dyscalculia and dyslexia: Different behavioral, yet similar brain activity profiles during arithmetic. NeuroImage: Clinical 18, 663-674. 
Richards, T.L., Grabowski, T.J., Boord, P., Yagle, K., Askren, M., Mestre, Z., Robinson, P., Welker, O., Gulliford, D., Nagy ,W., \& Berninger, V. (2015). Contrasting brain patterns of writing-related DTI parameters, fMRI connectivity, and DTI-fMRI connectivity correlations in children with and without dysgraphia or dyslexia. NeuroImage: Clinical 8, 408-421.

Rudel, R. G. (1985). Hemispheric asymmetry and learning disabilities: Left, right or in between? In C. T.Best (Ed.), Hemispheric function and collaboration in the child (pp. 275-308). San Francisco: Academic Press.

Shaywitz, B. A., Shaywitz, S., Blachman, B., Pugh, K., Fullbright, R., \& Skudlarski, P.(2003). Development of left occipito-temporal systems for skilled reading following a phonologically-based intervention in children. New York : Paper presented at the Organization for Human Brain Mapping..

Sinatra, R.(1983). Interrelations of brain learning style (ERIC) Document Reproduction Service N. ED339708.

Solso, R. L. (2004). Cognitive Psychology. 6th. ed. Singapore: Pearson Education.

Springer, S. \& Deutsch, G. (2003). Left Brain-Right Brain, (6th. ed). New York: W.H. Freeman. 